\title{
Yeşilçam'da Polisiyenin Eleştirel Dönüşümü: Toplumsal Gerçekçi Sinema Hareketinin Amblemi Olarak Gecelerin Ötesi
}

\author{
Tunç Yıldırım (Dr. Öğr. Üyesi) \\ Munzur Üniversitesi Meslek Yüksek Okulu \\ tyildirim@munzur.edu.tr
}

Başvuru Tarihi: 08.05.2018

Yayına Kabul Tarihi: 13.06.2018

Yayınlanma Tarihi: 30.07.2018

Öz

Türk sinemasının Yeşilçam öncesi uzun süren dönemi polisiye türü konusunda pek üretken değildir. Yeşilçam sinemasının oluşum döneminde (1948-1959) kitlesel film üretiminin sistemleşmesiyle birlikte beş hâkim sinema türü (melodram, tarihi film, komedi, polisiye ve köy filmi) standartlaşır. Bu türsel bağlamda yapımcılığına dönen Kemal Film için Lütfi Akad-Osman Seden ikilisi, suç melodramı ile sembiyotik ilişkiye giren polisiyeler üretir: Kanun Namına, Katil, Öldüren Şehir, Kanlarıyla Ödediler ve Intikam Alevi gibi melez filmler 1952-1956 arasında melodram ile polisiye estetiğini suç ve macera temaları etrafında harmanlar. Kemal Filmin basmakalıplaştırdığı polisiye türe toplumsal, siyasal ve iktisadi yeni bir eleştirel görünüm kazandıran, ayrıca bu türü hem içerikte hem de biçimde modernleştiren eser toplumsal gerçekçi sinema hareketinin öncüsü Gecelerin Ötesi'dir. Böylece, melodramın klişeleşmiş uzlaşımlarından nihayet kurtulan polisiye türü realizm ile senkretik bir bağ kurar. Film sanatının olmazsa olmazları biçime ve biçeme olduğu kadar sinemasal türlere de odaklanan "estetik tarih" perspektifinden hareket eden bu makalenin amacı, Türk sinema tarihyazımında türsel kimliği görmezden gelinip sadece sosyal ve realist temsilleri hatta sosyolojik yönleri etrafında değerlendirilen Gecelerin Ötesi'nin polisiyeyi nasıl yenilediğini kanıtlamaktır. Gecelerin Ötesi hangi estetik özellikleriyle hem polisiye türüne hem de toplumsal gerçekçi harekete girer? Bu film, Akad-Seden tandeminin temellerini attığı polisiye film geleneğinden neden ve nasıl farklılaşır? Çalışmanın problematiği bu çerçevede belirlenmiştir. Makalenin teorik çerçevesi ve analitik yöntemi ise "sinema türü kavramını" basit bir taksonomi etkinliği ya da etiketleme şekli olarak değil de, ciddi bir "yorumlama kategorisi" olarak kabul eden Raphaëlle Moine’ın kuramsal yaklaşımına dayanır.

Anahtar Kelimeler: Metin Erksan, Gecelerin Ötesi, toplumsal gerçekçilik, polisiye, suç filmleri, yorumlama kategorisi olarak film türü, eleștirel alımlama.

\footnotetext{
* Bu çalıșma 2-5 Mayıs 2018 tarihleri arasında İstanbul'da düzenlenen XIX. Türkiye Film Araştırmalarında Yeni Yönelimler Konferansı'nda 'Yeşilçam'da Polisiyenin Eleştirel Dönüşümü: Toplumsal Gerçekçi Sinema Hareketinin Amblemi Olarak Gecelerin Ötesi" başlığıyla sunulan bildiridir.
} 


\title{
The Critical Transformation Of Detective Movie in Yeşilçam Cinema: Beyond the Nights As the Emblem of Social Realist Film Movement
}

\author{
Tunç Yıldırım (Asst. Prof. Dr.) \\ Munzur University Vocational School \\ tyildirim@munzur.edu.tr
}

Date Received: 08.05.2018

Date Accepted: 13.06.2018

Date Published: 30.07.2018

\begin{abstract}
The period which took long time before Yeşilçam was not so productive in terms of detective movie. During the genesis of Yeşilçam period (1948-1959), five dominant film genres (melodrama, historical, comedy, detective and village movies) got standardized by the systematization of mass film production. The tandem of Lütfi Akad and Osman Seden produced the detective movies in symbiotic relationship with crime melodrama for Kemal Film, which got back to the production in this typical context: The hybrid movies such as In the Name of the Law, Murderer, The Killing City, They Paid with Their Blood and The Flame of Vengeance combined melodrama and detective aesthetic around the themes of crime and adventure between 195256. Beyond the Nights which was the precursor of social realist film movement is the piece which brought a new critical image socially, politically, and economically the detective genre stereotyped by Kemal Film, and also, modernized this genre in terms of both content and form. By this way, the detective genre which got away from the conventions of melodrama established a syncretic link to realism. The aim of this article starting from the perspective of "aesthetic history" which focuses on cinema genres as much as on form and style among the basics of movie art is to demonstrate how Beyond the Nights renovates detective movies. It had been assessed only based upon its social and realist representations, and even its sociological aspects by ignoring its genre identity in Turkish cinema historiography. With which aesthetical aspects does Beyond the Nights take place both within the detective movie and social realist movement? How and why does this film differentiate from the tradition of detective movie initiated by the tandem of Akad-Seden? The problematic of this study was defined within this framework. The theoretical aspect and analytical method is based upon the theoretical approach of Raphaëlle Moine who considers "concept of cinematic genres" not only to be a simple taxonomy activity or labeling, but also a "category of interpretation."
\end{abstract}

Keywords: Metin Erksan, Beyond the Nights, social realism, detective movie, crime films, film genre as a category of interpretation, critical reception. 


\section{Giriş}

Yönetmen ve senaryo yazarı Metin Erksan'ın 27 Mayıs 1960 darbesinden önce çevirmeye başladığı, bugün neredeyse 60 yaşında olan Gecelerin Ötesi hakkında yapılan yakın tarihli tematik okumalar filmin polisiye türü ile ilişkili türsel kimliği hakkında hiçbir șey söylememektedir. Mesela, bu filmin sinema araştırmacıları ve tarihçileri tarafından yeterince detaylı bir şekilde değil, ana noktaları itibariyle bile incelenmediğini düșünen Erksan uzmanı Kayalı’ya göre (Bkz. 2004, 85-87) “Gecelerin Ötesi, İstanbul ekseninde sosyolojik bir tahlil olarak anlaşılabilir." Kayalı için bu eser çok önemlidir çünkü Gecelerin Ötesi'ndeki karakterlerin özelliklerini Erksan'ın sonraki filmlerinde de görmek mümkündür $(2018,438)$. Keza toplumsal gerçekçi hareketin Türk sinemasındaki oluşumunu çözümleyen Daldal $(2005,97-98)$ bu eleştirel filme sadece toplumsal, iktisadi ve siyasal tabanı etrafında bakarak Gecelerin Ötesi'ni toplumsal gerçekçiliğin ilk örneği olduğu genel görüşünü yineler. Erksan film anlatısının merkezine yerleştirdiği alt-orta sınıf yedi şehirli genç üzerinden emek sömürüsü, yabancılaşma, yasadışı çocuk işçi çalıştırma sorunu, fakirlik çıkmazı ve yalnızlık sıkıntısı gibi standart türlere dayalı dönemin Türk sinemasında neredeyse hiç rastlanmayan sosyoekonomik ve psikolojik temaları işlese de, onun toplumun alt kesimlerini kapsayan ve bu alt katmanlara özellikle önem veren sosyal gerçekçi yaklaşımı ilk olarak kendisini 1958'de Dokuz Dağın Efesi filminde gösterir. Osmanlı mazisini, kahramanlaştırılan muktedirleri üzerinden yüceltmeyen dolayısıyla geçmişçi ve romantik-milliyetçi olmayan bu değişik tarihi filmin odak noktasında kanun kaçağı erdemli bir eşkıyaya dönüşen küçük Anadolu insanının sosyal yaşamı vardır (Bkz. Yıldırım, 2017, 49). Erksan'ı saf bir auteur yani sanat eseri olarak filmin biricik sahibi yaratıcı yönetmen olarak kabul eden Altıner $(2005,37)$ Gecelerin Ötesi'ni ilk toplumsal gerçekçi film olarak etiketlemekle yetinir ama bu film ya da başka bir Erksan filmi üzerinden auteur yaratıcılığının polisiyeyle yahut standart tür sinemasıyla nasıl bir yaratıcı estetik ilişkiye girdiğini çözümlemeyi düşünmez. ${ }^{1}$

Her şeye rağmen tüm bu toplumbilimsel, toplumsal ve auteurist akademik tekyönlü görüşlerin dışına çıkmayı başarabilen iki ender yoruma rastlamak da mümkündür. Bir başka deyişle, Gecelerin Ötesi'nin toplumsal gerçekçi özelliğini vurgularken filmin polisiye türü ile bağlantısını göstermeyi ihmal etmeyen dikkatli yorumlar da mevcuttur. Türk sinemasını türlere göre sınıflandırmayı ve sıralamayı amaçlayan sinema tarihçisi Özgüç'e göre $(2005,134)$ 'Gecelerin Ötesi hem bir 'gençlik filmi' hem de toplumsal bir eleştiri getiren polisiye deneme olarak dikkati çeker." Filmdeki ikili yapıyı görebilen ve polisiye türüyle sosyal eleştiriyi iç içe değerlendiren Algan için $(2017,30)$, toplumsal gerçekçi sinemanın en belli başlı örneklerinden biri olan Gecelerin Ötesi, bunun yanında polisiyenin, kara sinemanın anlatım öğelerini, estetiğini kullanmada oldukça başarılıdır.

Zaten Gecelerin Ötesi'nin yaydığı temsiller üzerinden sadece toplumsal gerçekçi tarafını öne çıkaran profesyonel görüşlerle, toplumsal yanının ve polisiye yönünün altını birlikte çizen amatör okumalar aslında yapaydır çünkü sinema tarihini yazarken türleri gerçekçiler (yani olgusal mantığa boyun eğmiş somut gerçeğe başvuranlar) ve gerçekdışılar (yani saf düşsellikten ileri gelenler) şeklinde ikiye bölen sinema tarihçisi ve estetikçisi Mitry $(1980,171)$ hem şiirsel gerçekçilikten hem psikolojik gerçekçilikten farklılaşan toplumsal gerçekçiliği şöyle tanımlar: "Toplumsal bağlam tarafından belirlenmiş dramlar." Mitry'e göre (171) toplumsal gerçekçiliğe dâhil olan türler şunlardır: "Suç veya polisiye maceraları. İdeolojik savunmalar. Westernler. 
Savaş filmleri." Mitry’nin tarifine göre (247) gerçekçilik mefhumu, "somut gerçekten kaynaklanan her şeyi nesnellikle göz önünde bulundurmak zorundadır." Mitry'nin sadece içerik değerlendirmesi üzerinden toplumsal gerçekçi çerçeveye yerleştirdiği polisiye türü önemlidir. Çoğu polisiyenin yaşanmış, gerçek bir olaya dayanması hatta gazetelerin üçüncü sayfalarında iz bırakan, toplumda geniş yankı uyandıran soygun, cinayet gibi suç temalarını işlemesi bu türün gerçeklikle olan yakın ilişkisinin kanıtıdır. Anlaşılacağı gibi Türk sinema tarihyazımında Gecelerin Ötesi'nin toplumsal gerçekçi hareketi başlatan film olarak tanınması onun polisiye olarak değerlendirilmeyeceği anlamına gelmemelidir çünkü bu öncü filmin yaydığı sosyal ve eleștirel temsiller onun türsel kimliğinin tespitiyle doğru orantılıdır. Bir başka deyişle, filmin sahip olduğu iç içe geçen ikili melez estetik yapı (yani polisiye ve gerçekçilik karakteristiği) olası çözümlemeyi daha karmaşık kılmaktadır.

Sanatta gerçekçi estetik meselesi kendisini çok önceleri gösterse de, II. Dünya Savaşı biterken İtalya'da ortaya çıkan ulusal sinema hareketi Yeni Gerçekçilik sayesinde savaş sonrası gerçekçi sinema hem yapım hem de kuram olarak fiziki ve ruhsal enkaz halindeki Avrupa'da filizlenir. Sinemasal gerçekçiliğin olası taksonomisini yapım, dağıtım ve işletim tarzları etrafında biçimlendirmek isteyen Nagib'e göre (2017, 310); kendisini dünya sineması olarak tanımlayan gerçekçi sinema, daha kesin olarak, 1940’larda "gerçeğe belgesel bir yaklaşım temelindeki" İtalyan Yeni Gerçekçiliğiyle başlar ve "bu yeni gerçekçi sinema ekranda aşırı yoksulluğun cesur gerçekliğini açıklar." Onun için (310) "bu temel hareketin ham estetiği ve vahiy gücü de, dünyada sonradan ortaya çıkan (toplumsal) gerçekçi ekollerin (1950'lerde bağımsız Hint sineması, 1960'larda Brezilya Yeni Sineması, 1970'lerde bağımsızlık-sonrası Afrika sineması, 1980'lerde Yeni İran Sineması, 1990'larda Danimarka Dogma 95'i ve diğer birçok yeni dalgalar ile yeni sinemalar) telaşına ilham vermiştir." Daldal'ın (2005, 44) "sosyal sinema deneyimi", "eleştirel gerçekçi” ve "gözlemci” gibi ortak öğeler üzerinden Türk toplumsal gerçekçiliği ile İtalyan Yeni Gerçekçiliği arasında kurduğu belirgin bağ önemlidir çünkü ona göre söz konusu İtalyan sinema hareketi adı geçen Türk sinema akımına ilham kaynağı olmuştur. Şehir, köy ortamlarındaki toplumsal kaygılar, sürekli vurgulanan gerçekçilik derdi ile dekorların ve durumların hakikati düşünüldüğünde her iki sinema hareketini meydana getiren olmazsa olmaz unsurlar kolayca tespit edilebilir.

Biricik davası gerçekçilik olan bu sinema hareketi sadece İtalya dışındaki angaje yönetmenleri etkilemez çünkü "Yeni Gerçekçiliğin etkisi altındaki teorisyenler taklitçi, ortaya seren ve gerçekçi sinemadan yana oldular" ve "André Bazin ve Siegfried Kracauer gibi teorisyenler, kameranın farz edilen içsel gerçekçiliğini demokratik ve eşitlikçi estetiğin köşe taşı yaptılar. (Stam, 2014, 83-84)" Stam'ın yorumuna göre (85) hem Bazin hem de Kracauer için "sinemanın görüngüsel görünüşleri mekanik olarak yeniden üretimi, sinemanın gücünün anahtarı idi.” Realist, mimetik ve fenomenolojik sinema teorisinin akla ilk gelen iki temsilcisi olan Bazin ve Kracauer, "sinemanın özünü, çıplak gözle görülemeyecek bazı fenomenler de dâhil olmak üzere gerçekliği kaydetme ve yeniden-üretme becerisi ile tanımlar. (Elsaesser ve Hagener, 2011, 33)" Sinema tarihinde iz bırakmış yönetmenleri görüntüye (imaja) ve gerçekliğe (realiteye) inananlar diye ikiye bölen Bazin'in sinemasal gerçekçilik kavramında Yeni Gerçekçilik mihenk taşıdır çünkü onun tasarladığı şekliyle sinema tarihindeki gerçekçi geleneğin evrimi, İtalyan Yeni Gerçekçiliği ile doygunluğa ulaşır. (Bkz. Nagib, 310 ve Stam, 86-87) Aslında, bir çeşit gerçeklik estetiği olarak İtalyan Yeni 
Gerçekçiliğine tamamen bağlanan Bazin, Elsaesser ve Hagener'in açıkça bahsettiği üzere (56-57), "kamerayı doğru konuma yerleștirip önünde ne varsa kaydetmeye bırakıldığı zaman filmin dünyayı olduğu gibi gösterebileceğine inanıyordu." Fiziksel dünyayı, estetik kavrayışın asli malzemesi yapan Kracauer (2015, 516-518) tarafından "sinema fiziksel gerçekliğin kurtarılmasını destekleyecek özel bir mecra olarak tanımlanabilir." Sinemanın fiziksel gerçekliği yaşatabilme yetisi ve hayatı somut olarak ekranda yansıtması üzerinde duran Kracauer'e göre (516), "film fiziksel gerçekliği kaydedip keşfederken, herkesin erişiminde olduğu için bulunamayan bir dünyayı gözler önüne serer."

Bugün Türk sinemasının en istisnai yaratıcılarından biri olarak göklere çıkarılan Metin Erksan'ın kariyeri boyunca Yeşilçam denen ticari sinema ortamında film çekmek zorunda kaldığı, bu sebepten de ağır türsel koşullar içinde kendi sanatçı imzasını taşıyan özgün eserler verebildiği hatırlanmalıdır. Yarı bağımsız olarak kabul edilebilecek Susuz Yaz (1963) ve tam bağımsız Sevmek Zamanı'na (1965) kadar Erksan, Türk sinemasına tamamen hükmeden tür sineması çerçevesinde mecburen eser vermiştir. ${ }^{2}$ Bağımsız yapım tarzının ve estetik açıdan nitelikli filmlerin ortaya çıkmasını amaçlayan sanat sineması kurumunu ${ }^{3}$ destekleyecek bir milli sinema politikasının olmadığı sinema ortamında zaten aksi düşünülemez. Resmi sansürün tamamen tahrif ettiği Karanlık Dünya (1952) isimli gerçekçi köy filmi denemesinin başarısızlığından sonra Erksan'ın sinemaya yönetmen olarak dönebilmesi ancak bir polisiye uyarlama olan Beyaz Cehennem (1954) ile mümkün olmuştur. Bu uyarlaması Cingöz Recai serisini yaratan yazar Peyami Safa'ya aittir. Küçük'e göre $(2016,293)$ aydın romanları yazan bu romancı, Server Bedi imzasıyla polis romanları denemesi de yapmıştır. Bu hızlı polisiyenin ardından yine bir edebiyat uyarlaması olan ve suç (cinayet) temasını işleyen Yolpalas Cinayeti (1955) Erksan'ın imza attığı ilginç bir filmdir. Demek ki, Türk edebiyatının roman türünden ödünç alınan suç veya polisiye anlatıları senarist-yönetmen Erksan'ın henüz kariyerinin başında dikkatini çeken tematik unsurlardır.

Ayrıca onun ilk tarihsel filmi Dokuz Dağın Efesi'ni çekerken bile resmi arşiv belgelerinin kanun kaçağı bir şaki yani adi bir suçlu olarak tanımladığı Çakıcı Mehmet Efe'yi sosyal yaşamını temel alarak ekrana getirme çabası dikkatle tahlil edilmelidir. 0 yıllarda revaçta olan efe filmleri basitçe aşk ve macera anlatıları kurmakla yetinip iyilerle kötüleri çarpıştırırken ve Yeşilçam'ın romantik milliyetçi tarihi filmleri de Osmanlı mazisini muktedirleri, kahramanları, büyük adamları üzerinden geçmişçi bir hayranlıkla ölçüsüzce överken Erksan'ın bu eseri biyografik bir temelden hareket ederek Osmanlı toplumsal tarihine eleștirel yaklaşmayı hedefler. ${ }^{4} \mathrm{Kısacası}$, Gecelerin Ötesi ile Demokrat Parti'nin 1950'lerdeki liberalizm siyasetini eleștirmeden ve bu iktisadi uygulamaların cemiyet nezdinde sebep olduğu sosyal kayıpları göstermeden önce Erksan, Dokuz Dağın Efesi ile kendi ülkesinin toplumsal geçmişine eleştirel bakabilmiştir. Bu da entelektüel bir yönetmen olarak Erksan'ın, Yeşilçam'ın standart tür sineması dâhilinde eser verirken bile farklı davranacağının, basmakalıp temsilleri değiştirebileceğinin hatta standart kalıpları aşacağının işaretidir.

Zaten Gecelerin Ötesi'nin ortaya çıkmasından hemen önce Türk sineması gerçekçi momentine girmiştir bile. 1958'de Üç Arkadaş ve 1959'da Yalnızlar Rıhtımı "melodramatik gerçekçi" estetiği Yeşilçam’a taşıyan melez tür filmleridir. İlki komedi ile melodramı, ikincisi de melodram ile gangster filmini; uzun çekimlere, plansekanslara, alan derinliğine ve eşzamanlı modern mizansene dayalı gerçekçi bir 
estetik biçimde, üslupta harmanlamayı başarır (Bkz. Yıldırım, 2016a, 3187-3197 ve Yıldırım, 2016b, 172-194,197-198). Memduh Ün ile Lütfi Akad'ın bu filmlerinde sosyal manada yapamadığını ${ }^{5}$ ise Dokuz Dağın Efesi'nde Metin Erksan, efe filmi alttürünü basit bir aşk-macera semantiği olmaktan çlkararak ve tarihi film türünü romantik, milliyetçi ve melodramatik içerikten koparıp gerçekçi, toplumsal ve trajik bir temele oturtarak başarır. Gecelerin Ötesi'nde Erksan, polisiye türü melodramla melezleștiren Akad-Seden ikilisine ait geleneksel standartlaşmış yapıyı farklılaştırarak yani polisiyeyi gerçekçilikle senkretik bir ilişkiye sokarak başarıyla çeşitlendirir.

$\mathrm{Bu}$ yazının nihai hedefi her çeşit kural koyucu, değer biçici, auteurist ve sinefilik okumalardan uzak durarak Gecelerin Ötesi'nin hem toplumsal gerçekçilikle hem de polisiye türle nasıl bir sembiyotik ilişkiye girdiğini betimlemek ve çözümlemektir. Çağdaş sinema araştırmalarında olmazsa olmaz bir yer işgal eden tür sineması perspektifinden hareket eden bu makalenin amacı, Türk sinema tarihyazımında türsel kimliği yani türselliği görmezden gelinip sadece sosyal ve realist temsilleri üzerinden değerlendirilen Gecelerin Ötesi'nin polisiyeyi nasıl yenilediğini kanıtlamaktır. Çalışmanın varsayımı adı geçen eserin türsel aidiyetini görmezden gelmeyen böyle bir kuramsal yaklaşım sayesinde Gecelerin Ötesi'nin tarihsel açıdan açıklanabileceği ve gelenek içine oturtulabileceği görüşüne dayanmaktadır.

Bu makalenin problematiği şöyle belirlenmiştir:

- Gecelerin Ötesi hangi tema, biçim ve üslup özellikleriyle toplumsal gerçekçi sinema hareketine ve hangi anlambilimsel ve sözdizimsel öğeleriyle polisiye türüne girer?

- Gecelerin Ötesi melez bir polisiye film olarak kendinden önce yani Yeşilçam sinemasının oluşum aşamasında (1948-1959) çevrilmiş ve standartlaşmış öteki polisiyelerden neden ve nasıl farklılaşır?

Bu çalışma toplamda üç alt bölümden oluşur:

Yazının teorik çerçevesini ve araştırma yöntemini açıklayan ilk bölümde sinema türü kavramını sistematik betimleme yapmaya yarayan basit bir tasnif mekanizması olarak değil, aksine ayrıntılı bir "yorum kategorisi” olarak kavramlaştıran ve sinema türünü gelişmiş bir analitik yöntemle çözümlemeyi uygun gören Raphaëlle Moine'in kuramsal görüşleri incelenecektir. Bu kısımda aynı zamanda polisiye film türü tanımlanacak ve onun suç üzerine kurulu temel özellikleri yani mümeyyiz vasıfları sergilenecektir.

İkinci bölüm ise Gecelerin Ötesi öncesinde Yeşilçam'da üretilen ve yaygınlaşan geleneksel polisiye filmlere, sinemadaki polisiye külliyata, özellikle de Akad-Seden ikilisinin imzasını taşıyanlara odaklanacaktır. Polisiyenin Türk sinemasındaki tarihsel arkaplanını inceleyen bu kısım aynı zamanda dönemin genel ve uzman basınında kendisini gösteren eleştirel söylemin isimlendirdiği, sınıflandırdığı ve ayırt ettiği standart türler içine özenle yerleştirdiği polisiyeyi nasıl değerlendirdiği üzerinde duracaktır. Unutmayalım ki sinemada türler, basitçe filmler içinde değil ama filmler hakkında üretilen söylemlerden de tespit edilebilir.

Son bölüm; tarihsel, kültürel ve sinemasal bağlamı içine yerleştirilen Gecelerin Ötesi'nin çok yönlü tahliline dayanacaktır. İlk aşamada bu filmle alakalı yan metinlere (ilan, reklam, afiş, tanıtım, fotoroman) bakılarak eserin türsel kimliğinin vurgulanıp vurgulanmadığı tespit edilmeye çalışılacaktır. Sonra filmin eleştirel alımlama analizi yapılarak ticari gösterime çıktığında "toplumsal gerçekçi" veya "polisiye" 
etiketleriyle anılıp anılmadığı ve nasıl yorumlandığı gösterilecektir. Ardından filmin içsel parametrelerine odaklanan ayrıntılı türsel çözümlemesi gerçekleştirilecek ve Gecelerin Ötesi toplumsal gerçekçi bir polisiye film olarak a posteriori tanımlanacaktır. Böylece adı geçen filmin polisiye türsel kimliğini ve toplumsal gerçekçi yönünü hiç görmeyen eleştirel söylemle bu filmi sadece toplumsal gerçekçi olarak tahlil etmeyi ısrarla sürdüren akademik söylem aşılacaktır.

\section{Kuramsal Çerçeve ve Araştırma Yöntemi: Yorumlama Kategorisi Olarak Sinema Türü ve Yaygın Bir Tür Olarak Polisiyenin Başat Özellikleri}

Sinema tarihinde sanatsal bakımdan büyük etki bırakan filmlerin bütün türleri aştığını ön kabul eden görüş, tür kavramının sanat eserinin hakikatini anlamaya engel oluşturduğu gibi bir peşin hüküm ve tabii ki bazı sinemacı-kuramcıların ${ }^{6}$ türü özgür sanatsal ifadenin köstekleyicisi olarak algılaması sinema araştırmaları içinde bile türlere önyargı ile yaklaşılmasına sebep olmuştur. Henüz 1920’lerde sinemanın yedinci sanat olarak meşruiyetini ispatlaması ve diğer seçkin güzel sanat dalları arasındaki saygın yerini alması belki de onun tarihinin dâhi mertebesine çıkarılan bir avuç yaratıcı yönetmen, yeni ilginç estetik biçimler üreten sinema hareketleri/ akımları/ekolleri ve ayrıksı bireysel üsluplar çerçevesinde bölümlendirilmesine ve okunmasına yol açmıștır. Bir de buna, eleștirel kuramın yaratıcısı Frankfurt Okulu'nun tesirinde kalınarak tür kavramının sürekli kitle kültürü ve kültür endüstrisi bağlamlarında değerlendirilmesi, daha doğrusu, değersizleştirilmesi eklenince sinemada tür incelemeleri arka plana atılmıştır.

I. Dünya Savașı'ndan itibaren dünya hâkimi konumuna gelen stüdyo sistemi üzerine kurulu sadece ticari Hollywood sinemasının değil, pek çok ulusal sinemanın uzun tarihlerinde ortaya çıkmış veya dışarıdan ödünç alınmış, popülerleşmiş, standartlaşmış, çeşitlenmiş, yok olmuş, dirilmiş türler mevcuttur. Bu türler çoğu kez kurumsal temsil tarzını yani öyküsel, temsili ve endüstriyel klasik sinema estetiğini dünya çapında yaygınlaştırmıştır. Moine'nin dediği gibi $(2004,6)$, "Hollywood sineması filmleriyle aynı zamanda türlerini de ihraç eder ve bu türler ulusal sinematografilerde yeniden ele alınabilir ve parodileştirilebilir." Böylece dünyada türler hakkında bir bilinç oluşur. Zaten sinema tarihçileri Thompson ve Bordwell'e göre (bkz. 2003, 5) sinema tarihinde kullanılan farklı açıklama tiplerinden biri olan "estetik tarih" yaklaşımı film sanatının şu üç öğesine odaklanır: form, stil ve tür. Moine için (4) sinema tarihi yalnızca filmsel metinlerin ve biçimlerin tarihi değil ama aynı zamanda eserlerin yapım, yorumlama ve alımlama uygulamalarının tarihi ve eserlerin dolaşım ve yayımlanma tarihi olarak kabul edilmelidir.

Tür yalnızca edebiyat, tiyatro ve resim gibi sanat dallarına ait yapıtları belirlemek için kullanılmaz. "Film türü ne işe yarar?" gibi çok net bir soru soran Delaporte'ye göre (117) "tür, filmsel nesnelerin üretimlerinden alımlamalarına kadar süregiden öncelikli bir kategorileștirme tarzıdır." Sinema türünü ampirik bir kategori olarak kabul eden Moine için $(2008,7)$ tür nosyonu; eserleri adlandırmaya, ayırt etmeye ve sınıflandırmaya yarar ve kendi aralarında biçimsel ve tematik benzerlikler bütünlüğü olan eserleri açlklamakla yükümlüdür. Ona göre (7-8) biz bir filmi bir türle eşleștirdik mi o filme türsel bir kimlik veriyoruz demektir. Moine'nin bakış açısından (9) karşılaştırılabilir özelliklere sahip belirli sayıdaki filmler, türsel bir kategorinin yaratılması için yetersiz de olsa gerekli şarttır. Bu bakımdan sinema türü; edebiyat, tiyatro, resim veya müzik türleri gibi hem eserler sınıfı hem de eserler grubu olarak ortaya çıkar. Biz, bir filme türsel bir kimlik verirken onu bir kategori 
içine yerleştirmekle yetinmeyiz ama o filmi aynı zamanda, benzer tematik, anlatısal ve biçimsel özellikler sunan bazı filmlerle seri haline sokarız (8). Yalnız tam da bu noktada, Delaporte'nin (117) şu hatırlatmasını yani "tür nosyonunun her şeye rağmen bireylere ve bağlamlara göre farklı gerçeklikleri içinde taşıdığını" mutlaka akılda tutmak gerekir.

Filmlerin özelliklerini belirlemek/belirginleştirmek için eleştirmenlerin ve araştırmacıların türsel adlandırmaları bilhassa kullanmaları türün, sıralama aracı ve muhtemel betimleme kategorisi olarak harekete geçirilmesi manasına gelir (Bkz. Moine, 2009, 9). Bu kapsamda yapılan iş, çeşitli film nevilerini tasnif etmeye yani sınıflandırmaya yarayan basit bir taksonomidir hatta etiketlemedir. Bu yolda ilerleyen meraklı bir araștırmacı sinemasal türler hakkında en fazla sistematik bir sınıflandırma olan tipoloji ortaya koyabilir. Oysa sinema türü fenomeninin kesinlikle anlaşılması ve hakkaniyetle tetkik edilebilmesi için daha gelişmiş bir teorik perspektife ve analitik metoda ihtiyaç duyulmaktadır. Moine (9) bunu yapabilmek için sinema türleri kuramının; sıralama kategorisi olarak tür kavramının yerine, "yorumlama kategorisi olarak tür kavramı"nı geçirmesi gerektiğini açıkça yazar. Peki, yorumlama kategorisi olarak sinema türü ne anlama gelir? Ana özellikleri nelerdir? Bir araştırma yöntemi olarak nasıl kullanılır?

Moine'nin (13-14) kuramsal çerçevesinde yorum kategorisi olarak tür yaklaşımı, bir türün tarihini yazarken ve tahlilini yaparken sadece o türün grupladığı filmsel metinlerin tarihi ve tahlili olmaz ama o türün kimliğini saptayan türsel kategorinin ya da kategorilerin de tarihi ve tahlili olmak zorundadır. Bu yöntem, yorumlama kategorisi olarak tür mefhumunun film külliyatının analizinden vazgeçtiği anlamına gelmez, bilakis çözümlemeye rehberlik eden varsayımların ve niyetlerin bilincinde olarak bunun yapılmasını talep eder. Ayrıca; Moine'a göre (15) tür yorum kategorisi olarak tasarlandığında faal kavram türün kendisinden çok türsellik olur çünkü söz konusu olan șey filmin bir türle ya da türlerle hangi ilişkiye girdiğini, filme hangi türsel kimliğin verileceğini ya da verildiğini, filmler hakkında söylenenleri ve filmleri türsel bir etiketle gruplandırınca orada görülenleri anlamaktır. Nihayetinde türsellik nosyonuna başvurma bir filmle bir tür arasındaki ilişkilerin aşırı derecede çeşitli olduğunu telkin eder. Moine'nin de dediği gibi (16) “tanıtımla, medyayla ve bilimle ilgili söylemler, farklı niyetlerden kaynaklansa da, türsel yeniden tanımlama uygulamasını devam ettirir." Moine'ye göre (Bkz. 2004, 2), betimleyici kategoriyi bir kez aşmak demek sinema türlerinin yalnızca film türleri olmadığını ama sürekli yer değiştiren yapım ve yorumlama kategorileri de olduğunu kavramak demektir. Ona göre (4), "sınıflayan türün arkasında her zaman bir sıralayıcı saklanır, sıralamanın da arkasında yorumlayıcı bir tavır ve strateji gizlice yer alır."

Moine için (Bkz. 6) açık bir eleştirel yöntem kullanılarak yapılması gereken tür çözümlemesi taksonomi mantığını aşarak tür nosyonunun temel ikilemini/ikiliğini dikkate almalıdır: "Sinema türü 'bir külliyatı, bir grup filmi' ve 'türün ismini, türsel etiketi, tür bilincini' gösterir." Son tahlilde Moine'nin sinema türünü bir yorum kategorisi olarak kabul eden kuramsal çerçevesi, tür sineması ile Hollywood müzikal güldürüsü uzmanı Rick Altman'ın yöntemini ödünç alarak tetkik edilen herhangi bir türün anlambilimsel ve sözdizimsel düzenlenişinin ortaya çıkarılmasını gerektirir (Bkz. 2008, 54-61 ve 2004, 8). Mesela, Delaporte'nin (47) verdiği örnek, polisiye odaklı bu makalenin içeriği düşünüldüğünde hayati bir önem taşır: "Soruşturmacının varlığı (anlambilimsel özellik) ile sorușturma anlatısı (sözdizimsel özellik), 'polis 
filmi' türü nezdinde, birlikte yaşar." Stam'a göre $(2014,138)$ de Altman, "pek çok filmin bir janrın sözdizimselliği ile bir başkasının semantiğini karıştırarak yenilikler yapabileceği" konusunda uyarıda bulunmuştur. Son tahlilde Moine'ye göre (20), "anlambilimsel seviye 'ne dendi?' sorusuna tekabül ederken, sözdizimsel seviye 'nasıl dendi?' sorusuna denk düşer." Aslında, türleri modellerken anlambilimsel olarak "belli bir dizi bileşen" beklenirken, sözdizimsel olarak da "belli bir anlatı yapısı" beklenir (Bkz. Butler, 2011, 123).

Peki, bir sinema türü olarak polisiyenin özellikleri nasıl tanımlanabilir ve sınırları nasıl çizilebilir? Bu türün görüldüğü an tanınması için yeterli, gerekli ve kendisini tekrar eden ölçütler var mıdır? "Polisiye filmi" kategorisini mi yoksa "suç filmi" terimini mi kullanmak daha doğru olur? Hangi sözcük ötekini kapsar? Tüm bu sorulara cevap vermek mecburi olduğu için sinemadaki polisiye meselesi hakkındaki farklı görüşleri kesiştirmek ve karşılaștırmak gerekmektedir.

Bir tarafta, polisiye geniş bir kategori olarak kabul edilirken polisiye film türü dendiğinde akla suçla başlayan bir anlatının soruşturmayla/tahkikatla devam etmesi ve neticesinde suçlunun tutuklanması gelmektedir (Bkz. Pillard, 2012, 9). Journot'a göre $(2004,95)$; polisiye, bazen soruşturmadan başka bir şey anlatmak için polise karşı gelen serserileri sahneleyen film türü anlamına gelir. Özön için (2000, 548-549) "gerçekte polis filmi birçok çeşitlemeyi kapsayan geniş kapsamlı bir terimdir." Zaten ona göre (649) "türler dolayısıyla kalıplaşmalar oluşabilir; bu kalıpları kırıp türü geliștirme, genişletme, yenileștirme çabaları kendini gösterebilir." Moine $(2008,46)$, polisiye filmin renkli film baskın konuma geldikten sonra bile Fransa'da olduğu gibi Hollywood'da da siyah-beyaz kullanımıyla farklılaştığını yazar. Uzun süren bu görsel estetik tercihi tamamlayan ikonografik çözümlemeye göre, yani tür filmlerinde kendilerini sürekli yineleyen simgesel imgelere dayanan yaklaşım için, polisiye filmi özel dedektife ya da komisere ait gabardin palto ile tanımlanabilir (49).

Sinemaya özgü türleri ve hareketleri özenle tasnif etmeye çabalayan Pinel'e göre (2009, 171) “1950’li yıllardan itibaren polisiye film tüm dünyada uygulanan ve sonu gelmeyen türlerden biri olmuştur." 0 , polisiye filmin çok fazla alttüre dağıldığını söylemekle beraber, türün isteyerek doğal dekoru ve belgesel bir işleyişi kullandığını not düşer. Pinel için (170-171) çok rağbet gören bu tür, suç filminin hâkim bir eğilimini oluşturur. Genellikle polisiye film, soruşturmanın nesnel akışına bağlanmış doğrusal yani çizgisel bir yapıya sahiptir. Pinel tarafından (66) hiçbir türdeşliği olmayan geniş bir alan olarak tanımlanan suç filminin sınırları içinde daha iyi tanımlanmış türlerden biri olarak kabul edilen "polisiye film, suçluların bulunmasından sorumlu kamu düzeninin resmi temsilcilerini birinci plana alır." Demek ki polisiye film, Pinel için özerk bir tür değil de, suç filmi denen daha büyük ve karmaşık türün, gangster filmi ve film noir (yani kara film) ile birlikte kapsadı̆̆ı bir çeşit alttürdür. Anlaşlacağı gibi suç, suçlu ve şiddet öğelerinden oluşan "üçlü yapı" üzerine kurulu suç filmi türü, polisiyeye nazaran çok daha geniş kapsamda düşünülmekte ve çözümlenmektedir. Peki, suç filmi nasıl tanımlanır? Butler'e göre (121), "ortada işlenen bir suçun olduğu ve olayın aydınlatıldığı bir film, suç filmidir." Yine de suç filmini karmaşı, türdeş olmayan, üç büyük eğilime parçalanabilir bir tür olarak kabul eden görüș (Vanoye vd., 2000, 48) için gangster filmi, film noir ve polisiye film içerik öğeleri ve anlatısal yapıları üzerinden birbirlerinden ayrılırlar. İşte bu bağlamda suç temasını ekranda işleme yollarından biri olan polisiyenin karakteristiği (polis ve suçlulardan meydana gelen ana kişiler, kentli mekân 
ortamının özellikle vurgulanması, zamandizine boyun eğen bir anlatı yapısı tercihi, gerçekçi tutum ve tavırları öne çıkarma) şöyle (48) sıralanabilir.

Tablo 1: Polisiye Film

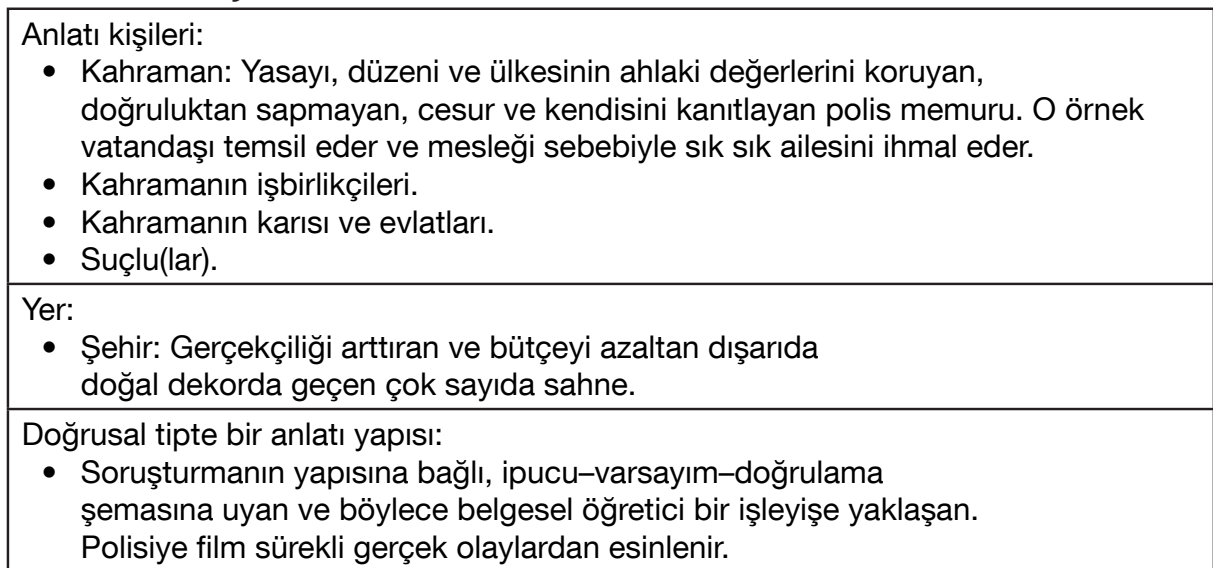

Özellikle Fransız sinemasındaki polisiye ve suç filmi türlerini tanımlamaya çalışan Berthé-Gaffiero için $(2005,203)$ "polis filmi, polisin eylemini sahneleyen film olarak" açıklansa da bu türsel etiketin esas özelliği muhakkak ki suç temelinde şekillenmelidir. Onun suç olgusunu türün anlatı yapısı ile kesinlikle ilişkilendiren bakış açısından (204), "suç, anlatının merkezi öğesi olmalıdır" ve "anlatının konusu her şeyden önce suç olmalıdır." Polisiye/suçlu filmlerini anlatı tarzları üzerinden ayırt eden Berthé-Gaffiero'ya göre (204-205) bazı filmlerde sorumluları bilinen bir suç işlenir. Anlatı, klasik sıralamayı takip ederek suç-öncesi, suç-sırası ve suç-sonrası ile öyküyü tastamam verir. Genellikle, suçlular kıstırılır ve beșeri adalet tarafından cezalandırılır. Bazen bu adalet yazgının görünümüne de bürünür. Bu kategorideki filmler, bir suçlunun gidişatını ve bizim uygarlaşmış toplumumuzun ona vereceği muhtemel cezayı çizmek için kullanılır. Bu durumda biz (yani seyirci) suçun kim tarafından işlendiğini biliriz ama anlatı, neden ve nasıl sorularına cevap verir. Demek ki ister polisiye film anlatısı olsun ister suç filmi anlatısı diye tanımlansın suç, suçun temsili ile soruşturması ve suçlunun cezalandırılması olmazsa olmaz bir bileșendir. Bir dönem Fransız sinemasındaki ve televizyonundaki örneklerin gözlemlenmesine dayanarak Moine $(2008,146)$, polisiyenin her zaman hakikatin keşfedilmesiyle ve toplumsal bir temsil içinde düzenin yeniden kurulmasıyla bittiğini söyler. Yine de, Jullier ve Marie'nin dediği gibi $(2007,55)$ "bir filmin belirli bir türe ait olduğunu anlamak için hiçbir kural olmadığını” unutmamak gerekir. Onlara göre en iyisi filmi, bir prototiple karşılaştırmak ve hangi ölçüde ona benzediğini araştırmaktır.

\section{Bulgular: Macera, Cinayet, Gangster ve Polis Etiketleriyle Tanımlanan Yeşilçam'ın İlk Polisiyeleri}

Türk sinemasının Yeşilçam döneminde atılıma geçen polisiye sinema bir tür olarak kabul edilebilir mi? Dönemin uzman ve genel basınında emeklemeye başlayan eleştirel söylem ile polisiyenin alametifarikası olan bazı filmlerin birlikte incelenmesi ancak bu hayati soruya akla uygun ve tatmin edici cevaplar verebilir. Altman'a göre (bkz. 2003, 331) tür oluşturma oyununda tek oyuncular film yapımcıları değildir çünkü eleştirmenler ve izleyiciler de bunda pay sahibidir. Eleștirel söylem ile türlerin tarihsel olarak adlandırılması arasında çok yakın bir ilişki olduğundan Moine'nin (128) dediği gibi bir sinema türünün doğuşu onu isimlendiren ve belirten ortak bir bilinç düzeyinin oluşumuna bağlıdır. 
Türk sinemasının ilk polis filmi örneği olarak Muhsin Ertuğrul'un 1929 yapımı Kaçakçılar verilmektedir (Özön, 2013, 103). Yine de Yeşilçam öncesi dönemde, polisiye denince akla gelen en ilginç film Faruk Kenç'in 1940'ta çevirdiği Yılmaz Ali' dir. Türk sinemasına tarihi bir merakla dışarıdan bakan şarkiyatçı görüş için Yılmaz Ali, olağanüstü teatral bir Louis Feuillade ${ }^{7}$ tarzı polisiye filmdir (Thoraval, 1996, 359). 1950'lerden itibaren tüm dünya sinemalarında polisiye filmin yaygınlaștığını belirten Pinel'i doğrulamak için Özön'ün de (130) Türk sinemasında bu türün 1951'den sonra birdenbire yaygınlaștığını tespit etmesi hatırlanmalıdır. Peki, polisiye türün Türk sinemasında patlama yapmasını sağlayan öncü film hangisidir? Uzun yıllar sonra yapımcılığa yeniden başlayan Kemal Film için Osman Seden'in mütareke dönemi İstanbul'unda yaşanmış gerçek bir olaydan hareket ederek yazdığı, Kani Kıpçak'ın 1951'de çektiği ve içeriğinde cani, çete(ci)ler, komiser, polisler gibi gerekli anlambilimsel bileșenler (Bkz. Yıldız, 1951, 24) barındırmasına rağmen Hrisantos/ İstanbul Kan Ağlarken bir dönüm noktası değildir.

Akad-Seden ikilisinin aynı yapımevi için ertesi yıl hazırladığı yakın tarihte gerçekten yaşanmış bir seri cinayet olayından esinlenen Kanun Namına polisiyenin Yeşilçam'da yaygınlaşmasında, popülerleşmesinde ve standartlaşmasında itici bir işlev üstlenmiştir. Uzman basında çıkan bir eleştiri (Lüks Koltuktaki Adam, 1952, 7) türsel etiketlemeyi anında yapmaktadır: "Rejisör Lütfi Akad'ı bize, Türkiye'de ilk defa böyle mükemmel takipli polisiye film verdiği için tebrik edeceğim ama ufak tefek bazı noktalar için de tenkit edeceğim. (İtalik vurgulamalar benim)" 0 yılların belli başlı filmlerinde çeşitli roller alan tanıdık oyuncu Temel Karamahmut (bkz. 1953, 19) için Türk sinemasında polisiye filmler rağbet görmüş Kanun Namına'dan sonra yapılmaktadır. Teksoy'a göre (2007, 29) “Akad'ın Altı Ölü Var (1953), Katil (1953) ve Öldüren Şehir (1954) filmleri hep Kanun Namına'nın çizgisini sürdüren ve Amerikan polisiye sinemasından esinlendiği görülen örneklerdir."

Peki, polisiyenin Yeşilçam'ın oluşum aşamasında standartlaşan türlerden biri olduğunu ispatlamak mümkün mü? 0 devrin Türk sinemasının görgü tanı̆̆ı olan eleştirel söylemin yorum, görüş ve tespitleri karşılaştırıldığında ekseriyetle 19521957 yılları arasında üretilen polisiye filmlerin Türk sinemasına egemen olan beș temel türden bir olduğu hemen anlașılır. ${ }^{8}$ Hem genel basında (Vatan) hem de özel basında (Yeditepe) sinema yazıları ve film eleștirileri kaleme alan Attila İlhan, üniversite öğrenciliği sırasında Paris'te edindiği engin sinema kültürü sayesinde ülkesine döndükten sonra yakından takip ettiği Türk filmleri ve sineması hakkında ilginç tespitler yapmıştır. Ona göre (1954a, 3), yönetmenlerin ancak sıkı bir türsel çerçeve içinde eser verebildiği Türk sinemasının ticari tür sinemasına bağımlı olan estetik niteliği standarttır: "Türk sinemasının bugün için işlediği konular ticari planda standartlaşmış denebilir. (Köy filmleri, tarihi filmler, melodramlar, polis filmleri ve açı seçik komediler.)"

Bu eleștirmenin tespit ve tasdik ettiği standart tür sinemasının Türk sinemasındaki mutlak hâkimiyetini vurgulayan bir başka dikkat çekici görüş de sanatsal niteliği yüksek film yapımını teşvik edip ödüllendirmek isteyen Türk Film Dostları Derneği'nin (TFDD) Başkanı ve Vatan gazetesi sinema eleştirmeni Burhan Arpad'a $(1955,5)$ aittir. 0, yabancı sinematografik türlerin nüfuz ettiği Türk sinemasının başat türlerini dörde ayırır ve Amerikan polisiye film türünün geleceğin Türk sineması için olası önemini vurgular: 
Son yıllarda sadece bir kemiyet olarak karşımıza çıkan Türk filmlerini, keyfiyet olarak dört nevide mütalaa edebiliriz:

1. Arap filmlerinin benzeri.

2. Amerikan gangster filmi benzeri.

3. İtalyan realizmi benzeri.

4. Orta oyunu ve kanto halitası yerli müzikal film.

Bir yılda sayısı elliyi bulan filmlerimizin arasında bu dört nev'in dışına çıkan bir 'Türk filmi'ne rastlamak henüz nasip olmadı. Belki de bir müddet daha beklemek icap edecek. Buna rağmen son yılların mamulatını bu dört tesir zaviyesinden gözden geçirince, Amerikan polisiye filmi ile İtalyan realist üslubu film hususiyetlerinin yarınki 'Türk filmi'nde esaslı tesirleri bulunabileceği neticesine varabiliriz. (İtalik vurgulamalar benim)

İlhan gibi polisiye türün yaygınlığına ve filmsel bakımdan türsel sınırla(n)ma sorununa dikkat çeken Arpad, Kanun Namına'yı sanatsal bakımdan çok başarılı bir film olarak değerlendirirken eseri polisiye film olarak değil de, "hareketli ve heyecanlı bir macera filmi" türü şeklinde etiketlemiştir $(1952,4)$. Henüz başat türleri sınıflandırmadan bir sene önce, Orhan Elmas'ın Üçüncü Kat Cinayeti filmini ele alan Arpad (1954b, 4) "son yılların Türk filmciliğinde melodram ve polisiye örneklerin ağır bastığını" yazmaktadır.

Demek ki Türk sinemasında gerçekte 1952' de başlayan polisiye filmi furyasına, 1954 yllında edebiyat sahasında kara roman türü üzerinden yaşanan kültürel patlama eşlik eder. ABD'li muharrir Mickey Spillane'nin I, The Jury kitabını ünlü romancı Kemal Tahir, F. M. İkinci mahlasıyla Kanun Benim şeklinde Türkçeleștirir (Bkz. Üyepazarcı, 2015-2016, 102). Adi suçlular, cani haydutlar ve acımasız meşum kadınlarla mücadele eden kurnaz polis hafiyesi, büyük dedektif Mike Hammer serisinin cep kitapları yok satar. Sadece bir sene içinde, çok okunan bu polisiye dizinin XXI. kitabı Bu Gece Son Gecesi başlığıyla çıkar (bkz. Milliyet, 1955, 3).

1956'da dönemin muhalif ve siyasi haftalık dergisi Akis'de eleștiri yapmaya başlayan Halit Refiğ (1956a, 27), tür sinemasına karșı peșin hükümlü bir ideolojik tavırla hareket eder. 0 , Türk sinemasında gerçekçi yani realist estetiğin mutlaka yerleşmesini istediği için dönem dönem revaçta olan tür filmlerini (tarihi filmler, polisiye filmler, müzikal melodramlar, köy filmleri, çocuklu aile melodramları vs.) "sinemanın periyodik hastalı̆̆ı" olarak kabul eder. İlhan, Arpad ve Refiğ gibi nitelikli üç eleştirmenin yazdığı metinler polisiyenin standart bir tür olarak dönemin popüler Türk sinemasında önemli bir yer edindiğini ispatlamaktadır. Peki, polisiye tür sınıflaması içinde yer alan (ya da alabilecek) filmler hangi özellikleriyle dikkat çeker ve nasıl bir eleştirel alımlama ile karşılaşır? Mümeyyiz vasıfları nelerdir? Bu tür hakkında tenkitçilerin "beklenti ufku" nasıl yapılanır?

İster gangster filmi ister polis filmi terimleriyle etiketlensin bu alanda Kanun Namına'dan ${ }^{9}$ sonra dikkat çeken ikinci film Çetin Karamanbey imzalı İstanbul Canavarı'dır. Arpad'a göre (1953a, 4), İstanbul'da çalışan eroin şebekeleri ile zabıtanın mücadelesini belirten bu filmde, gangster filminin heyecan ve takip atmosferi başarıyla bulunurken, vakanın ve kahramanların beşeri tarafları hiç yoktur. Eleştirmen için İstanbul Canavarı'nın en büyük kusuru, doğrudan doğruya Amerikan filmlerinden mülhem olan Kanun Namına'nın taklidi olmasıdır. Yani öz bakımından kesinlikle başarısız olan yeni bir taklit söz konusudur. Dünya gazetesinde yaklaşık bir ay kadar "Kamera" takma ismiyle sinema eleștirmenliği yapan genç yönetmen Metin Erksan, ağabeyinin çektiği bu film üzerinde dikkatle durur. İstanbul Canavarı'nı tıpkı 
Arpad gibi Amerikan gangster filmi türü içine oturtan Erksan (1953a, 4), eserin biçimsel yönden övgüsünü yaparken özdeki ve içerikteki eksiklikleri (yani kanundışı adamların bu duruma gelişlerinin sosyal, ekonomik ve psikolojik sebeplerinin verilmeyişi ile senaryonun olayların sebeplerini açıklayamaması) şiddetle tenkit eder. Erksan'ın İstanbul Canavarı ile Kanun Namına arasında en ufak bir biçimsel benzerlik olmadığını iddia eden sonraki yazısı (1953b, 4), Kanun Namına'nın önce Fransız sonra Amerikan filmlerinden kopya edildiğini henüz yeni kavrayan Arpad'ı yerden yere vurur. Erksan'a göre $(4,7)$ beşeri tarafı eksik olan İstanbul Canavarı, Naked City (New York Esrarı ${ }^{10}$ ) isimli Amerikan filminden ilham alır. Kanun Namına'nın özgün bir tarafı olmadığını iddia eden kızgın eleştirmen daha ileri giderek bu janrda Türkiye'de yapılan filmleri kendi sinema beğenisine göre sıralar: “1) Ístanbul Canavarı, 2) Affet Beni Allah'ım, 3) Kanlı Para, 4) Kanun Namına."

Kanun Namına'yı neredeyse mükemmel bir polisiye olarak niteleyen Lüks Koltuktaki Adam için (bkz. 1953a, 21), bir sürü heyecanlı ve kanlı macera içeren, Ayhan Işık'ın canlandırdığı önemli anlatı kişilerinden birinin "zabıta romanları muharriri" olduğu Kanlı Para milyonluk bir define peşinde koşanların hesaplaştığı, fenaların (yani kötülerin) cezalarını gördükleri Orhon M. Arıburnu imzalı "polisiye macera" filmidir. Yönetmen Şinasi Özkonuk'un çevirdiği narkotik bir sorunu temel alan Affet Beni Allah'ım, aynı yazar için (1953b, 15), eroin imalatçısı çetelerin birbirleriyle ve polisle mücadelelerini gösteren "gangster filmidir". İki yılda artarda çevrilen bu dört filmin eleștirel alımlaması, eleștirel söylemin sıklıkla kullandığı iki türsel etiketin (polisiye ve gangster) yaygınlaştığını ispat eder. Eleştirmenler artık bu tarz filmlere karşı türsel bir bilinç kazanır.

İhtilaf yaratan İstanbul Canavarı'ndan sonra tıpkı Kanun Namına gibi yaşanmış gerçek bir suç olayına dayanan İpsala Cinayeti (Altı Ölü Var) ile Akad kendisini yönetmen olarak bir kez daha ispat eder. Erksan'ın yönetmenliğe dönmesinden sonra Dünya'daki sinema tenkidi sütununu "sinopsis" mahlasıyla devralan Semih Tuğrul $(1953,4)$ bu müspet filmi türsel bir etiketlendirme ile değerlendirmez ve 1937'de yaşanan gerçek bir cinayet vakasının "vesikalar ile zabıta kayıtlarına dayanılarak" özenle senaryolaştırıldığını hatırlatmakla yetinir. Kanun Namına'yı çok beğenip macera filmi olarak takdim eden Arpad (1953b, 3) için yetenekli rejisör Akad artık, "cinayet ve macera filmlerinde" karar kılmıştır. Altı Ölü Var'ı da cinayet filmi olarak etiketleyen Arpad, ne Kanun Namına'yı ne de bu son filmi polisiye türü kapsamında tasnif eder. Genel basında yazan her iki eleştirmen de suç yani cinayet kavramına odaklanarak filmi değerlendirme yoluna gider.

Yönetmen Akad, senarist Seden ve türün olmazsa olmaz erkek başrol oyuncusu Işılk'ı bir kez daha buluşturan Katil filmi için Arpad'ın (1953c, 5) olumsuz görüşleri çok nettir. Kemal Film yapımevini sürekli cinayet ve macera filmleriyle eșleștiren yorumuna göre yabancı film ithalatçılığında olduğu gibi yerli film imalatçılığında da "avantürcü" olan bu şirketin Katil isimli eseri tam bir avantür (macera) filmidir. Filmin önceki örneklerden farkını ve başarısızlığını içerikte yani özde bulan Arpad için senaryo zaafının asıl sebebi eserin bu sefer "gerçek vaka nakline değil" de Seden'in kaleminden çıkan bir hikâyeye dayanmasından ileri gelir. Eleştirmenin tespit ettiği şekilde artık Türk sinemasında cinayet ve macera türlerinde sistematik olarak sürekli film üreten bir yapımevi vardır. Katil filmi yorumu ile birlikte artık bu türün konvansiyonel standardının yerleștiği ancak basmakalıp tekrarının eleștirildiği ve çeşitlenmesinin beklendiği anlaşılmaktadır. 
Akad ile Seden'i buluşturan sonraki film Öldüren Şehir için Tuğrul'un filmin ait olduğu tür hakkında görüşleri $(1954,4)$, Arpad'ın önceki türsel tasnif çabasıyla uyuşur. Ona göre ortada konusu ve işlenişi itibariyle iddialı olmayan "hareketli ve sürükleyici bir avantür filmi” vardır. Macera bileșenlerini özetleyen Tuğrul için Öldüren Şehir'deki bazı planlar Akad'ın önceki filmi Katil'i bir hayli hatırlatmaktadır. Yönetmen için tekrar yaparak kendini yineleme sorunu aşikârdır. İşin garip tarafı Arpad'ın Öldüren Şehir hakkındaki eleștirel tavrı onu, Erksan'ın Kanun Namına hakkındaki sitemkâr görüşlerine yaklaştırır (1954a, 4). Bu filmle birlikte Arpad ilk kez olarak Akad'ı "gangster özentisi Amerikan film taklitçiliği" yapmakla sert şekilde itham eder ve böylece, o ana kadar cinayet ve macera filmleri ile bir tutmayı yeğlediği bu yönetmeni ve Kemal Filmin ikinci yapımcılık devrini apaçık şekilde gangster türü (dolayısıyla polisiye) içine dâhil eder. Hem hayranlık ve takdir hem de yabancı türsel kökenden kaynaklanan bir sitem ve ayıplama içeren şu alıntı bu eleştirmenin Öldüren Şehir'e karşı ikircikli daha doğrusu paradoksal yaklaşımını özetler:

Öldüren Şehir, rejisör Lütfi Akad ve Kemal Film için şunları da söylemek kabil: İyi iş yapan Amerikan gangster filmlerinin ticari şanslarına peşinen sahip olmak endişesi, bütün iyi niyetleri, mali ve teknik imkânları ve sanat seviyesini, önceden sımsıkı bağlıyor. Buna rağmen Kemal Filmin ikinci faaliyet devresinde (Hrisantos'dan beri) verdiği en başarılı eseri. ${ }^{11}$ (İtalik vurgulamalar benim)

Arpad bu türsel kimliği açıktan belli eseri, Amerikan sinemasının nüfuzunda kalınarak ticari kaygılar içinde çevrilen bir iş filmi olarak yadırgasa da, söz konusu filmin sanatsal başarısını kabullenmek durumunda kalır ve ona değer biçer. Türe damgasını vurup polisiyeyi Türk sinemasının gündemine sokan Kanun Namına'yı göklere çıkaran ama Altı Ölü Var'ı hiç beğenmeyen Lüks Koltuktaki Adam (1954, 3), nam-ı diğer Sezai Solelli ise Öldüren Şehir'i çok beğenerek bu eserin "gangster ve macera filmi” olarak çok güzel olduğu sonucuna varır. Böylece, Kemal Film bünyesinde Akad-Seden tandemi tarafından sürekli üretilen bu tarz filmlerin üç eleştirmen (Arpad, Tuğrul, Solelli) tarafından polisiye-macera-gangster-cinayet terimleri etrafında melez olarak kümelendirilmesi netlik kazanmaktadır. Dikkat çeken nokta eleştirel söylemin melezleştirmeyi "polis-macera", "gangster-macera" ya da "cinayet-macera" ikilemeleri şeklinde yapması ve hem yönetmeni hem de genellikle takdir toplayan, ilgi çeken polisiye filmlerini melodram estetiğine hiç yaklaştırmadan değerlendirmesidir. Dönemin eleştirmenleri nezdinde melodram tahammül edilemeyen bayağı bir tür olarak hakir görüldüğünden Türk sinemasında polisiye türünün şahikaları hatta kanonları olarak kabul edilebilecek Kanun Namına ${ }^{12}$ ve Öldüren Şehiri3 melodramla olası bir sembiyotik ya da senkretik ilişkinin dışında değerlendirilir.

Peki, Akad ile yollarını ayırdıktan hemen sonra kamera arkasına geçip yönetmenlik yapmaya başlayan Seden filmlerinde türün olmazsa olmaz bileşeni suç temasını işlerken polisiyeye mi yoksa melodrama mı yaklaşır? Bir başka deyişle bugüne ulaşamamış (ya da henüz seyredilemeyecek durumda olan) Öldüren Şehir bir tarafa konduğunda ${ }^{14}$, Kemal Film müessesine ait olan Kanun Namına (1952), Kanları ile Ödediler (1955) ve İntikam Alevi (1956) arasındaki melez türsel kimlik sürekliliği ve değişkenliği nasıl açıklanabilir?

Sinema tarihçisi Özön'e göre $(2013,185 ; 1968,122)$ Seden'in yönetmen olarak çevirdiği ilk film Kanları ile Ödediler "polis melodramlarının bütün beylik öğelerini bir araya toplamakta" ve "polis filmleri çı̆̆ırını devam ettiren filmlerdendir." 0, bu 
filmi polisiye ve melodramla harmanlayarak bir araya getirse de eleștirel söylem aksini iddia eder ve öncelikle melodram, sonrasında macera terimlerini kullanır. Yeni Yıldız'da (bkz. 1955, 23) verilen minicik jenerik bilgisi, filmi hem melodram hem de avantür türleriyle eșleştirir. Eleștirmen Özdeş'in $(1955,5)$ yorumu da "filmin mevzuunun hem dram hem de avantür unsurlarına dayanmasını" vurgulamaktadır. Kanları ile Ödediler'in melez türsel kimliğinin altını çizen bu görüşlere ek olarak Kakınç $(1956,8)$ "macera”, Refiğ $(1956 b, 26)$ ise "melodram" türünü ön plana çıkarır. Filmin ayrıntılı çözümlemesini yapan Yıldırım için $(2016 b, 170)$ Kanları ile Ödediler $^{15}$ "ahlakçı bir aile melodramıdır."

Refiğ'in (1956c, 24) Intikam Alevi eleştirisi çok sert hatta abartılı olup eseri olumsuz manada \% 100 melodram ile ilişkilendirir. Filmi, ortak özelliklere sahip aynı eser grubu içine oturtmak istemekte ama polisiye, gangster, suç veya başka bir tür ismini özellikle kullanmamaktadır. 0, Intikam Alevi'nin herhangi bir türle nitelendirmediği önceki örneklerinden neden farklılaştığını yani melodramlaştığını tüm ayrıntılarıyla açıklarken kendinden emindir. Kanun Namına, Ípsala Cinayeti, Katil, Öldüren Şehir gibi bir grup filmi hem "sosyal yahut psikolojik mevzuları işlemeye çalışmaları" hem de Amerikan sinemasından alınma "baş döndürücü hareketleri" etrafında olumlu değerlendiren eleştirmene göre bu “cereyan” yani akım çürüyüp kaybolmuștur. Bunun sebebi de mevzu yani konu ile birlikte hareketi de tamamen yok eden melodram türünün ağır ve tek taraflı estetik etkisidir. Intikam Alevi'ni böyle alımlayan Refiğ'in görüşlerini açımlarsak eğer, polisiye türünün mümeyyiz vasıfları kendisini melodramın baskın anlambilimsel karakteristiğine terk etmiştir. Bu eleştirmenin beklenti ufkunu ihlal ettiği için onun tarafından melodram olarak kötülenen Intikam Alevi diğer eleştirmenler tarafından 1952-1955 arasında polisiye, gangster, cinayet veya macera türleriyle etiketlenen film grubunun dışına atılır. Bir başka tenkitçi Esin $(1957,9)$ ise ticari başarıyı garantilemek için Akad'ın Katil'inin konusunu tekrar etmekle suçladığı Seden'e olumsuz not verir. Yıldırım'ın ayrıntılı türsel analizine göre (133) eklektik bir üslupla çevrilen İntikam Alevi ${ }^{16}$ melez bir türsel kimliğe sahip "gerçek bir polisiye melodramdır." Son tahlilde, 1950’ler Türk sinemasında Kemal Film nezdinde Kanun Namına'nın açtığı kapıyı İntikam Alevi kapamıştır.

Anlaşılacağı gibi Türk sinema tarihinin Yeşilçam'ın oluşumu diye adlandırılan bu dönemsel momentinde türün ismi (polisiye), melez türsel etiketlendirmeler (gangster, cinayet, macera, polis filmleri), türe ait ana filmler külliyatı (Kanun Namına, Kanlı Para, İstanbul Canavarı, Altı Ölü Var, Öldüren Şehir vs.) ve tabii ki eserleri ayırt edip, adlandıran türsel bilinç doğmuştur. İşte bu bağlamda gösterime çıkan Erksan'ın Beyaz Cehennem'i, Cingöz Recai isimli "polisiye roman serisinden filme alınmıștır" şeklinde okuyucuya tanıtılır (Bkz. Vatan İlave, 1954, 4). Aslında bu film açık bir edebiyat uyarlaması olsa da uyuşturucu kaçakçılığı sorununa el atan teması ve narkotik özü bakımından Affet Beni Allah'ım ve İstanbul Canavarı gibi önceki yılın filmleri ile aynı taraftadır. Ancak Arpad (1954c, 4) bildiğini okumaya devam ederek Server Bedi imzalı Cingöz Recai dizisini macera olarak kabul eder ve Beyaz Cehennem'in eroin kaçakçılığı meselesini işlemesinin altını çizmekle yetinir. Uzun süren "takip ve kovalamaca" öğesinden olduğu gibi "beyaz zehir teșkilatının" filmdeki varlığından bahsetse de eseri, "hoş ve hareketli bir film" ve "film anlayışı mevcut bir Türk filmi" olarak över. Polisiye, suç veya gangster türleriyle hiç ilişkilendirmediği bu filmin merkezinde ona göre aslen bir "macera kahramanı" olan Cingöz Recai kişisi vardır. ${ }^{17}$ 
Erksan'ın suç temasını işlemeye devam ettiği sonraki filmi Yolpalas Cinayeti de Halide Edip Adıvar'ın aynı isimli romanından uyarlamadır. Erksan'ın daha sonraları gözde temalarından biri olacak evlilik yoluyla sinıf atlama meselesi romanda mevcuttur. Günümüze ulaşmayan bu filmin hangi türe girdiğini kestirmek için yeterli delil yoktur. ${ }^{18}$ Milliyet gazetesinde film eleștirileri yapan ve filmlere yıldız vermesiyle ünlenen Tuncan Okan'ın Yolpalas Cinayeti okuması $(1956,7)$ filmin türsel kimliği hakkında kesin bir bilgi vermez. "Mahkeme”, "adli tıp", "cezaevi arabası", "cinayet suçundan yargılanan genç kızın mazisi" ve anlatımda "flashback" kullanımı gibi metinde yer bulan belli başlı bileșenler bazı ipuçları verse de eser polisiye mi, suç filmi mi yoksa suç melodramı mı? Bu soruyu doğru cevaplamak yani filmin ait olduğu (belki de melez) türü eldeki veriler ıșığında tahmin etmek mümkün değildir. Zaten Yolpalas Cinayeti hakkında uzman basında (Yeni Yıldız) çıkan biri tanıtım öbürü de eleștiri metni filmin olası türselliği konusunda tek kelime etmemektedir (Bkz. 1955, 28; 1956, 25).

Bu iki suç merkezli film ve haklarında yapılan yorumlar dikkate alındığında Erksan'ın yönetmen olarak 1950'ler polisiye türüne yaptığı katkının sınırlı olduğu anlaşılır. Onun türe asıl katkısı, Akad-Seden ikilisinin oluşturduğu geleneksel ikili yapının yani polisiye ile melodram senkretizminin dışına çıkan modern biçimli, toplumsal içerikli ve eleştirel gerçekçi polisiyesi Gecelerin Ötesi olacaktır. Bir başka deyişle Yeşilçam'ın oluşum döneminde standartlaşan polisiye türü çeşitlendirecek ve değiştirecek öncü yönetmen, auteur yaratıcılığını kullanacak Erksan olacaktır.

\section{Toplumsal gerçekçi bir polisiye olarak Gecelerin Ötesi}

DP iktidarına muhalif bir aydın olarak Erksan eleştirel ve gerçekçi eğilimi ile öne çıkan Gecelerin Ötesi ile kendini göstermeden hemen önce, yani 27 Mayıs 1960 darbesinin arifesinde ve ertesinde sinema çevrelerince hazırlanan iki önemli kolektif manifestoya imza atar. Bunlardan birincisi eleştirel söylemce çok beğenilen ve gelmiş geçmiş en iyi Türk filmi diye övgüsü yapılan Üç Arkadaş’ı itibarlı Uluslararası Film Festivali Cannes'e gönderme izni vermeyen dolayısıyla Türk sinemasının en güzel örnekleri vasıtasıyla bütün dünya ülkelerince tanınmasını engelleyen Basın Yayın ve Turizm Bakanlığı'nın ilave sansürünü protesto eden eleştirel bildiridir (Bkz. Gevgilili, 1959 , 2). Daha önemli ikincisi ise, 1939'dan kalma ve Faşist İtalya'dan alınma sansür nizamnamesinin anti demokratik bir kanun olduğu için tasfiye edilmesini talep eden "Türk Sineması İçin Hürriyet Beyannamesi" adlı radikal metindir (Bkz. Vatan, 1960, 5). 27 Mayıs 1960'ı "Hürriyet İnkılabı" olarak kabul eden bu yazı doğrudan işbaşındaki Milli Hükümet'e hitap etmektedir. İlk gerçekçi denemesi Karanlık Dünya'nın sansür tarafından tamamen tahrif edilmesi sebebiyle Erksan'ın sansür karşıtı özgürlükçü bir bildiriye imza atması anlaşılır. Onun DP’yi deviren 27 Mayıs 1960 darbesi sonrası aydın kesim ile ordu arasındaki yakınlaşmayı desteklediği bellidir çünkü kendi ifadesine göre (Ataç, 1962, 31) "Türkiye gerek bireyler, gerek kurumlar olarak mutlu bir hareket dönemine girmiştir."

Sınırlı bir özgürlük ortamı yaratacak olan 1961 anayasasıyla bir avuç sol görüşlü sinemacı (Erksan, Refiğ, Akad, Duygu Sağıroğlu, Ertem Göreç, Vedat Türkali) sansür tüzüğünün değiștirilmesini ya da kaldırılmasını sağlayamasalar da toplumsal sorunlara gerçekçi estetik çerçevede el atmaya cüret eden eserlere imza atarlar. Baskıcı sansürün sınırlamalarına rağmen gerçekçi çıkışların geleceği, yukarıda adı geçen bildirilerin imzalanmasından bellidir. "Türkiye'de 1960’lar ve Sinema” isimli panele (2007) konuşmacı olarak katılan Göreç’e göre Türk toplumsal gerçekçiliğinin 
iki kurucu babası Metin Erksan ve Vedat Türkali'dir. Tarihsel bakımdan Türk sinemasında toplumsal gerçekçi ${ }^{19}$ hareketin ilk filmi henüz darbe gerçekleşmeden önce çevrilmeye başlanan Gecelerin Ötesi olur. Toplumsal gerçekçi sinemanın ayrıntılı çözümlemesini yapan Daldal (2005, 60-61) için, Erksan bu akımın ilk örneği olarak kabul edilen Gecelerin Ötesi'nde "nesnel toplumsal inceleme" ve "sınıf bilinci yüksek bir şehir gerçekçiliği" vurgusu yapmaktadır. ${ }^{20}$ Peki, bu öncü filmin yapım, işletim ve eleştirel alımlama bağlamları için neler söylenebilir? Eser, önce yan metinlerde sonra da üst metinlerde toplumsal gerçekçi hareket yahut polisiye türü etiketlemeleri ile anılmış mıdır? Eleștirmenlerin beklenti ufkunda nasıl karşılanmıştır? Gecelerin Ötesi hakkında herhangi bir türsel bilinç oluşmuş mudur?

Yeşilçam’ın hiçbir büyük yıldızına yer vermeyen bu küçük bütçeli Erksan filmini onunla daha önce bir film yapmış IDHEC mezunu Nejat Duru'nun Ergenekon Filmi finanse etmiştir. Erksan'ın 1950'lerde çevirdiği filmler içinde gișede çok büyük başarı elde eden Hicran Yarası isimli melodramatik sazlı-sözlü-şarkılı aşk filmi sayesinde Gecelerin Ötesi isimli iddialı projesini gerçekleştirebilme imkânı bulabildiği așikârdır. Başarılı eseri sayesinde Erksan, ertesi yıl yine Ergenekon Film için Mahalle Arkadaşları'nı yazar ve yönetir. Filmin reklamı, dağıtımı ve işletimi de Erksan'ın önceki filmlerini yapmış Nazif Duru'nun Atlas Filmi himayesinde başarıyla yürütülür. Kasım ayı ortasında Gecelerin Ötesi için öncelikle Duru ailesinin işlettiği Yeni Atlas sinemasında gazeteciler için basın özel gösteriminin gerçekleştirildiği bir gala düzenlenir. Vatan'da $(1960,4)$ çıkan bir fotoğraf, filmin yönetmenini ve oyuncularını "çete" olarak takdim eder ve Erksan'ın filminde çete hikâyesi anlattığını not düşer. Kasım sonunda, uzman basının haftalık popüler dergisi Sinema'da (1960, 6-7, 34) Gecelerin Ötesi'nin fotoromanı "film hikâyesi" şeklinde yayımlanır. Tanıtım amaçlı çıkan bu reklam metni filmin fotoğraflarını sergilerken esas öyküyü zamandizinsel düzene uygun şekilde özetler ve ana kişileri takdim eder. Tarık Kakınç ve Ali Gevgilili gibi iki gerçekçi sinema taraftarı radikal sinema eleştirmeninin yeni çıkarmaya başladığı Yeni Sinema dergisinin 3. sayısında $(1960,18)$ çıkan Gecelerin Ötesi reklamı altı erkek anlatı kişisinin mesleklerini sunarken filmin sosyo-politik mesajı hakkında suçlayıcı bilgi verir. "Her mahallede bir milyoner yetiştirmeyi amaç edinen devrin, harcamayı göze aldığı, daha doğrusu harcadığı topluluk." Eserin reklam, tanıtım ve promosyon kampanyasını özenle düzenleyen bütün bu yan metinler filmin türsel kimliği hakkında suskundur.

Gecelerin Ötesi nihayet 19 Aralık 1960'da Ankara'da, 20 Aralık 1960'da İstanbul sinemalarında ticari gösterime çıkar (bkz. Yeni Sabah, 1960, 5). İlanda, Türk Sinema Sanatçlları Derneği Başkanı Baha Gelenbevi'nin filmi öven görüşü alıntılanır: “Bu film Türk sinemasını en az 10 sene ileriye götürmüş... Mutlu bir eser... Zevk ve onur duydum." Nejat Duru'nun babası Atlas Filmin sahibi Nazif Duru'nun büyük desteğini alan Gecelerin Ötesi'nin Türkiye dağıtımını Çınar Film üstlenir. Film 19 Aralık 19605 Ocak 1961 arasında Ankara, İstanbul, Eskişehir, Kütahya, Afyon şehirlerindeki sinema salonlarında seyirciyle buluşur. 20 Aralık'tan 5 Ocak'a kadar sinemanın kalbi İstanbul'da Beyoğlu, Kadıköy ve İstanbul cihetlerinde bulunan beş farklı sinemada (sırasıyla Yeni Atlas, Lâle, Şık, Küçük Emek, Hâle) oynar. İstanbul rehberi içinde filmin geçtiği sinemaları gösteren kısım da Gecelerin Ötesi'ni en önemli oyuncusu (Kadir Savun) ile anarken türsel özelliği hakkında hiç bilgi vermez. Filmin Beyazıt Devlet Kütüphanesi arşivlerinde saklanan özgün afişi de Yeşilçam'da birincil roller oynamayan oyuncular içinde Kadir Savun'un ismini en tepeye en büyük harflerle 
yazar. Bu afiște yer bulan ve filmin görselliğini anlamlandıran ikonografik öğelerin (karanlıkta farlarını açmış kamyonet, benzin istasyonundaki kırmızı variller, sert çizgilerle ve gölgelerle dışavurumcu tarzda resmedilmiş biri tabancasıyla ateş eden öbürü de yaralanan takım elbiseli iki vahşi erkek figürü ve afişin üst kısmını kaplayan yemyeşil ve kocaman bir kadın yüzü) eserin polisiye türü hakkında kesin bir fikir oluşturduğu söylenemez. Belki ateşli silah olarak revolverin varlığı, görsel olarak karanlık atmosferin vurgulanması ve meșum kadın karakteri anlamlandırabilecek dişil yüz bu türün bileșenleriyle ilişkilendirilebilir.

Peki, Gecelerin Ötesi'nin türselliğini ve sosyal gerçekçiliğini görmezden gelen yan metinlerin yanında eleştirel üst metinler ne düşünmektedir? Çetin A. Özkırım için $(1960,4)$ Gecelerin Ötesi senaryosu, rejisi, siyah-beyaz fotoğrafları, çerçevelemeleriyle ve oyunculuk (başta Savun) performanslarıyla başarılı bir filmdir. Filmin olası türünden ve gerçekçi yönünden hiç bahsetmeyen, eseri tarihsel açıdan açıklamaya girişmeyen Özkırım'a göre Erksan'ın cesurca bir davranış sergilemesi senaryosunu "bir gençlik problemi" üstüne kurmasından kaynaklanır. Refiğ $(1960,34)$ "bir iyi niyet gösterisi" olarak kabul ettiği Gecelerin Ötesi'nin sosyal açısından ve eleştirel yönünden olumlu olarak bahseden ilk eleştirmendir:

Film, her mahallede mantar gibi milyoner türetilmek istenen bir devrin bir başka yüzünü, o mahallelerde milyonerlerle beraber kötü ve karanlık yollara sapan bir takım gençlerin de var olduğunu açıkllyordu. Gecelerin Ötesi, her biri ayrı bir tutkuda yedi gencin hikâyesiydi. Erksan, bu yedi gencin hikâyesini geride bıraktı̆̆ımız devre ışıı tutarak, sosyal bir açıdan ele almıştı. (İtalik vurgulamalar benim)

Yalnız suç teması etrafında polisiye türünün etkisinden hiç bahsetmeyen Refiğ'in senaryo eleştirisine göre "gençleri benzin istasyonlarını soymaya iten ana sebeplerin layıkıyla açıklanamaması" Gecelerin Ötesi'nin eleștirilecek tarafıdır. Bu film hakkında en ayrıntılı çözümlemeyi bir yıl sonra ilk Türk sinema tarihi kitabını çıkaracak olan Nijat Özön $(1961,218)$ kaleme alır. Onun eleștirel söylemi Gecelerin Ötesi'nin tarihsel ve toplumsal önemlerini vurguladığı gibi gerçekçi özünün de altını çizer. Tıpkı Akis'teki çömezi Refiğ gibi Türk sinemasında tavizsiz bir gerçekçilik taraftarı olan müşkülpesent eleştirmenin beklenti ufkunu tamamen altüst eden gerçekçi, toplumsal ve eleștirel bir film söz konusudur:

\begin{abstract}
'Gecelerin Ötesi'yle değiş̧ik bir Erksan ortaya çıkmaktadır. Bir yandan Erksan'ın çok vakit yalnız tasarıda kalan bir toplumsal eleştirmeyi sansürün elverdiği ölçüde perdeye aktarabildiği görülüyor. [...] Konusu bakımında 'Gecelerin Ötesi', [...] Türk perdesine erişebilen en sert eleştirmedir. [...] Son on yıl içindeki toplumsal çöküntünün bir yanına el atan film, her mahallede yaratıldığı ileri sürülen bir milyonere karşılık ne kadar kayıp verdiğimizi yankılamaktadır. (İtalik vurgulamalar benim)
\end{abstract}

Filmin toplumsallığını, gerçekçiliğini, eleştirelliğini öven ve onu bu vasıfları üzerinden Türk sinema tarihindeki yerine oturtan Özön; "soygun", "çete”, "zabita olayı", "gerçek bir olaydan alınma hikâye" gibi polisiye semantiğini belirten türsel bileșenleri alıntılar ama Gecelerin Ötesi'nin türselliğini teğet geçer yani eseri türsüzleştirir. ${ }^{21}$ Böylece filmin polisiyeye pekâlâ dâhil olabilecek kimliğini görmezden gelir. Toplumsal eleștiri yapan Gecelerin Ötesi'nden övgüyle bahsetmesi de bu filmi toplumsal gerçekçi akım ya da hareket içine yerleștirdiği manasına gelmez tabii. Özön (1962, 180-181), ilk sinema tarihi kitabında Gecelerin Ötesi hakkındaki değerlendirmesini bu makalesinde olduğu şekliyle tekrarlar. 
İstanbul Belediyesi Sanat Festivali kapsamında düzenlenen II. Türk Film Festivali'ne iștirak edip en iyi senaryo ödülünü kazanan Gecelerin Ötesi hakkında yazar, senarist, eleştirmen Kakınç $(1961,4)$ ilginç yorumlar yapar. Ona göre tüm kusurlarına karşın bir iyi niyet ortaya koyan bu film, "Türk filmleri içinde yeni bir dönüm noktası oluyor." Eserin tematik yönden "batı sinemasının örnek çalışması suçlu gençlik problemine el atmasını" beğenen eleştirmen için filmin "gerçek bir çevreye" dayanması da önemlidir. Görüldügü gibi Gecelerin Ötesi'ni çözümleyen bu son tenkitçi de, ne toplumsal gerçekçi adlandırması ne polisiye etiketlemesi yapar. Filmin Türk sinema tarihinde dönüm noktası olarak değerlendirilmesinin hangi sebeplere bağlı olduğu veya neye göre olduğu da müphem kalır. Bu festivali yakından takip eden Özgüç (1961, 11-12) en başarılı film ödülü dağıtımından memnun değildir çünkü ona göre Gecelerin Ötesi "katıksız gerçekçiliğiyle" birincilik ödülünü hak etmiştir.

Demek ki, Gecelerin Ötesi'ni ilgilendiren yan metinlerin ve üst metinlerin birlikte gözden geçirilmesi, adı geçen sinema filminin herhangi bir türle ilişkilendirilmediğini, türsel bilinçle kavranmadığını, türsel etiketlemeye maruz kalmadığını ve tabii ki sosyal içeriği üzerinde özenle durulsa da Türk sinema tarihinde toplumsal gerçekçi hareketi başlatan bir film olarak görülmediğini ispatlamak için yeterlidir. ${ }^{22}$ Şimdi yapılması gereken eserin türselliğini anlambilimsel ve sözdizimsel özelliklerine dayanarak hakkaniyetli bir şekilde açlklayacak çözümlemeye geçmektir.

Polisiye türünün gerçekten yaşanmış olaylardan sürekli esinlendiği ve faydalandığı hatırlandığında suçu merkeze koyan Gecelerin Ötesi anlatısının gerçeğe, hakikate ve sahiciliğe dayalı tavrı hemen kendisini gösterir. Öyle ki, bu filmin senaryosu 19541957 yılları arasında Bursa dolaylarında vuku bulan benzin istasyonu soygunlarından faydalanılarak yazılmıştır (Bkz. Akis, 1960, 33). Gerçekten yaşanmış soygun olaylarına dayalı bu filmin çekimleri İstanbul'da sürerken özellikle Anadolu'daki benzin istasyonlarını hedef alan bir hırsız ve soyguncu şebekesinin yakalandığına dair haberler yazılı basında çıkar (Bkz. Vatan, 1960, 2). 1950'lerde filizlenen polisiyelerin ekseriyetle cinayet olaylarına dayanarak aile dirliği sorunsalını işlediği ve melodramla melezleştiği düşünüldüğünde kolektif bir suça dayanan Gecelerin Ötesi'nin ilk farklılığı hemen ortaya çıkar. Demek ki, suç temasını neden ve nasıl sorularına cevap arayarak işleyen Gecelerin Ötesi'nde 1950'lerin Türkiye'sinde kalmış kimi suçlar değil de, artık güncel hayatın bir parçasına dönüşmüş tanıdık bir suçun temsilleri işlenmektedir. Peki, bu suçun failleri kimlerdir? Film anlatısı bu soruya film jenerikle birlikte başladığında yanıt vermeyi uygun görür çünkü açıklayıcı bir yazı şu notu düşer: "Bu film 7 gencin hikâyesidir. Konu olduğu gibi hayattan alınmıștır. Her mahallede bir milyonerin türediği devirde, aynı mahallede bu gençler de türedi."

Gecelerin Ötesi'nde polisiye türünün sözdizimsel karakteristiği; kendisini üç aşamalı suç merkezli anlatı yapısında, soruşturma anlatısının ortaya çıkmasında ve bunların doğal sonucu olan polis ile suçlular arasından yaşanan takip-kovalamaca sahnelerinin kullanılmasında gösterir. Doğrudan yaşamdan alınan mevzunun, içlerinde bulundukları ekonomik düzenin kurbanları oldukları anlaşılacak aynı sosyal çevreden ve alt tabakadan bir grup gencin öyküsüne kaynaklık etmesi senaryocu-yönetmeni o güne kadar Türk sinemasının gördüğü en gerçekçi anlatı kişilerini sergilemeye yöneltir. Bu polisiye ekrana kaderin ya da alınyazısının kurbanı olan, melodram evrenine çok uygun şekilde arzu ile yasanın çatışması arasında kalmış tek bir bedbaht erkek anti-kahraman taşımaz! Kolektif suçu ortak anlatı kişileri etrafında çözümleyen senaryocu-yönetmen bu tavrıyla Türk polisiyelerinin 
kalıplarını kırar ve türü yenileştirir. Kamyon şoförü Fehmi, ehliyet almak ve evlenmek için uğraşan muavini Tahsin, dokuma işçisi Ekrem, işsiz ressam Ayhan, işsiz tiyatro oyuncusu Cevat, rock müzisyeni ve basketbolcu Yüksel ile parazit arkadaşı Sezai. $\mathrm{Bu}$ fakir gençlerden altısının çete olarak hareket eden suçlulara (hırsız, soyguncu, katil) neden, niçin ve nasıl dönüşeceklerini göstermekle başlayan Gecelerin Ötesi'nin suç merkezli anlatı yapısı polisiye türünün sözdizimine uygun olarak çizgisel yani doğrusal bir anlatımda gelişir. Kronolojiye tamamen sadık kalan bu klasikanlatı yapısı; hikâyeyi suç öncesi (çeteleşmenin psikolojik ve sosyoekonomik sebepleri), suç sırası (üçü başarılı biri başarısız soygun girișimi) ve suç sonrası (polis soruşturmasının başlaması, çetenin dağılması, takip-kovalamaca, yakalanma) aşamalarından dikkatle geçirerek yapılandırır. Kısacası, anlatının nesnesi hem sebepleri, hem temsili hem de sonuçları ve cezasıyla birlikte işlenen suçun kendisidir.

Çeteleşen gençleri suça teşvik eden ana sosyal sebepler bellidir: zorunlu çalışmaya ve ağır çalışma koşullarına bağlı yabancılaşma duygusu, emek sömürüsü ve tabii ki yoksulluk, işsizlik, firsatçı bir bireycilik. Kendi ideallerini, hayallerini bencilce de olsa gerçekleştirmek için paraya ihtiyaç duyan bu genç insanlar doğru yoldan çlkmak zorunda kalır. Böylece Erksan, eleştirmen olarak olayların sebeplerini veremediği ve kanundışı adamların bu duruma gelişlerinin sosyal, ekonomik ve psikolojik nedenlerini açıklayamadığı için eleştirdiği 1950'lerin ihtilaflı gangster filmi İstanbul Canavarı'nın tematiğini aşar. Film öyküsü boyunca hem gündüz hem de geceleyin sürekli filme alınan otoyol ve benzin istasyonu iki gerçek mekân olarak simgesel işlev yüklenir. Düşlerindeki hayatları yaşamak ya da hayatın ağır gerçeklerinden kaçmak için ağabey/reis konumundaki Fehmi liderliğinde üç benzin istasyonu soyan çete üyeleri bilmeden de olsa kendilerini bu duruma sokan DP'nin ekonomipolitiğinden örtük biçimde intikamlarını alırlar. 1950'lere hükmeden bu partinin ulaşım ve liberalizm uygulamaları sonucunda tüm ülkede karayollarının uzunluğu ile benzin istasyonlarının sayısı artmıștır ne de olsa.

Özellikle işçi sınıfına ait iki figür (Fehmi ve Ekrem), Kemal Filmin gelenekselleştirdiği 1950'lerin polisiye-melodramlarında gerçekçi bir bağlamda inşa edilmeyen Ayhan Işık'ın canlandırdığı arzu nesnesi temsiline sıkışan işçi karakterlerden (Kanun Namına'da ipek gömlek giyen tornacı ustası işçi ve İntikam Alevi'nde deri montu, beyaz t-shirtü ve kot pantolonu ile kasten Hollywood starı James Dean'e benzetilen araba tamircisi) kesinlikle farklılaşır. Uzun yıllardan beri mecburen yaptıkları ve aileleri için katlandıkları işlere tamamen yabancılaşmış bu anlatı kişileri kendilerini makinenin, kamyonun bir parçası gibi gören bunalımlı otomatlara benzemektedir. Biri ticaret öbürü de sanayi burjuvazisi tarafından sürekli sömürülen bu zavallı iki fedakâr proleter, çalışma ve ücret sorunlarını sınıfsal temelde bilinçlenerek çözmek yerine onlardan kaçarak uzaklaşmayı tercih eder. Kısacası, başkaları için çalışmak zorunda kalan bu işçiler özgürlüklerini tamamen yitirmiştir. Seden-Akad ikilisin çok yankı uyandıran Öldüren Şehir'inde Kasımpaşa'daki mütevazı evinden seyrettiği ihtişamlı Beyoğlu semtinin ışıltısına kapılan ve kötü yola düşen masum bir kızın melodramatik öyküsü arzu-yasa ikilemi etrafında polisiye türe eklemlenirken, Erksan'ın toplumsal gerçekçi polisiyesi Gecelerin Ötesi'nde Üsküdar'daki evinden İstanbul'un ışıklarını temsil eden Beyoğlu'na hayranlıkla bakan Tahsin'in nişanlısı Sema evliliğe giden yolda sabırla sevgilisinin ehliyet sınavını geçmesini ve işe başlamasını bekler. 
Erksan'ın bu film için yarattığı aktör Cevat karakteri de Türk sinemasının polisiye türüne yüksek edebiyatı doğrudan alıntılaması yoluyla entelektüel bir meşruiyet kazandırır. Ülkesinde yapılan tiyatroyu budala, sinemayı da cahil bulan bu kitap kurdu seçkinci, müşkülpesent komedyenin biricik amacı Anadolu'da sanat tiyatrosu piyesleri icra edebilmektir. Erksan çete elemanına dönüşecek bu anlatı kişisini yapılandırırken çok önemli edebi bir referans yapar. Rus yazar Dostoyevski'nin klasiği Suç ve Ceza romanının başkişisi Raskolnikov gibi bu aktör de kötü șeylere iyi şeyler yapabilmek için bulaşır ve tam da tiyatrosunda sergilediği adı geçen romandan uyarlama oyunda suçlu Raskolnikov'u canlandırırken polisler tarafından yakalanır. Tıpkı Raskolnikov gibi işlediği suçun kurbanı olan tiyatrocu Cevat'in esinlenmesi roman türünden gelmektedir. Modern bir sinema filmi olan Gecelerin Ötesi'nin romana ve tiyatroya bir başka deyişle öteki sanat dallarına doğrudan referans yapması, yönetmenin yansıtmacı estetik tercihinin izdüşümüdür. Görüldüğü gibi kendinden önce çevrilmiş geleneksel polisiye filmlerle eleştirel ilişkiye giren Gecelerin Ötesi'ndeki tüm bu yenilikler o tarihe kadar bu türde kendini tekrar eden kimi bileșenleri (basmakalıp anlatı kişileri, melodramla kurulan senkretizm) değiştirmekte ve çeșitlendirmektedir.

Polisiyenin bir başka sözdizimsel bileşeni olan soruşturma/tahkikat anlatısının nesnel akışı da suç tabanlı hikâyenin doğrusal anlatımını pekiştirir ve sağlamlaștırır. İşlenen suçlara karşı polis teşkilatının baş temsilcisi komiser İrfan, gerçeğin peşinden koşar ve ipucu-varsayım-doğrulama şemasını bizzat uygulayarak soruşturmayı ustaca yürütür. Böylece soruşturma anlatısı kendisini sıkça gösterir. Gecelerin Ötesi'nin suç ve soruşturma anlatısına dayanan, kronolojik ilerleyen yapısı içinde failleri yakalamak isteyen polislerle onlardan kaçmak isteyen suçlular arasında yaşanan klasik "takip-kovalamaca" öğesi de bir bileşen olarak yer alabilir. Söz konusu anlatı; suç öncesi durumla başlayan, suçların ardı ardına işlenmesiyle devam eden, soruşturmanın açılması ile hızla süren ve tüm suçluların bir şekilde cezalarını çekmesiyle son bulan çizgisel bir kuruluştadır. Bu bağlamda Gecelerin Ötesi isimli polisiye filmde gençleri suça iten toplumsal, iktisadi, psikolojik, bireysel hatta keyfi sebepler; suçun ortaya çıkması ve temsili; suç soruşturmasının düzenin koruyucusu kolluk kuvveti temsilcisi polisler tarafindan başlatılması; ana suçların (çeteleşme, soygun, cinayet, hırsızlık) devam etmesi, polis tahkikatının ipucu, varsayım, tanıkları dinleme, doğrulama şemasına uygun şekilde hızla ilerlemesi; suçluların tespiti ve adaletin tecellisi (cezalandırma, ölüm, hapis) sırayla yer alır.

Gecelerin Ötesi'nde polisiyenin anlambilimsel karakteristiğini oluşturan şu temel bileşenler de kendilerini ifşa eder:

- Suç teması: 1950'lerin polisiye-melodramlarının aksine bu filmde "kolektif" suçun ortaya çıkışı kıskançlığa, intikama yani bireysel melodramatik sebeplere dayanmaz.

- Gerçekten yaşanmış bir olaydan esinlenme: Yalnız öfkeden kaynaklı bireysel cinayetler dizisi değil de, çete eliyle gerçekleşen kolektif soygun söz konusudur. Erksan bu temayı toplumun parçası olan sıradan bireylerin meselesi olarak inceler.

- Soruşturmacı rolündeki polis ve şebeke halinde çalışan suçlulardan meydana gelen temel anlatı kişileri: En başta tahkikatı yöneten düzenin ihtiyatlı koruyucusu gabardin paltosu ile kendisini sürekli gösteren komiser İrfan, diğer polis memurları, çeteye yani soyguncu şebekesine dönüșen 6 kișilik arkadaş topluluğu. 
- Hep doğal dekorda ve kasten dış mekânlarda kendisini gösteren gerçek şehir ortamının vurgulanması: Özellikle Anadolu yakasındaki Üsküdar semti ve çevresi belgesel tarzda işlenir.

- Gerçekçi estetiği bilinçli olarak ön plana çıkarma: Bu tarz bir belgesel işleyişe, gece çekimlerinin alâmetifarikası olan, aydınlatmada siyah-beyaz zıtlığını vurgulayan ölçülü estetik atmosferik kullanımının eşlik eder.

Polisiyenin temel unsurlarını içinde barındıran Gecelerin Ötesi aynı zamanda modern sinema estetiğiyle yakından ilişkilidir. Özellikle Batı sinematografilerinde II. Dünya Savaşı sonrasında yer bulan gerçekçi sinemanın üslup özelliği olarak kendisini gösteren kimi tekniklere (zamansal ve mekânsal devamlılığı sağlayan uzun çekimler, doğal dekorda yapılan uzun kaydırmalı çekimler, klasik dekupajı reddeden plan sekans kullanımı, devamlılık kurgusunun olmazsa olmazı $180^{\circ}$ kuralının belli yerlerde bilerek çiğnenmesi, tuhaf kompozisyonlar yaratan çekim açıları tercihi, üçüncü boyutu vurgulayan alan derinliği kullanımı, eşzamanlı yani karmaşık mizansene yer verme, diğer kültür biçimlerine [en başta yüksek sanatı ve tefekkürü temsil eden edebiyatın roman türü] doğrudan yapılan göndermeler, sinemanın sanat(lar)ı yansıtması, eklektik tarzda müzik kullanımı ve mutlu sonu reddeden açlk uçlu sona başvurma ${ }^{23}$ ) Gecelerin Ötesi'nin modern biçeminde rastlamak mümkündür. Erksan'ın toplumsal gerçekçi bu filminde modern dekupaj tekniklerini belirgin şekilde kullanması onu tıpkı Renoir'ın 1930'ların sonlarında, tıpkı Welles'in 1940’ların başında ve tıpkı İtalyan Yeni Gerçekçiliği'nin 1945 sonrasında yaptığı gibi zamanın ve mekânın gerçekçiliğine yani derinlik ile süreklilik içinde düzenlenmiş gerçekçi imgeler yaratmaya yöneltir. Erksan eserinde klasik dekupajı radikal tarzda reddetmez ama onun şeffaflık estetiğini modern dekupajla birlikte kullanarak ortaya bir çeşit "melez dekupaj" çıkarır. ${ }^{24}$

Erksan'ın montajı, sadece takip-kovalamaca ve kavga sahnelerinde ritmini hızlandırır. Her ikisi de yaklaşık iki saat süren Seden'in mutlak hareket üzerine kurulu polisiye melodramı Intikam Alevi 941 plandan oluşurken (bkz. Yıldırım, 2018, 131-134), Erksan'ın toplumsal gerçekçi polisiyesi Gecelerin Ötesi sadece 669 plandan meydana gelir. Üstelik Erksan, klasik sinemada mekânsal geçişleri yumuşatmak ve zamansal geçişleri özellikle belirtmek için kullanılan zincirleme tekniğinden tamamen vazgeçer. Sekanslar arasındaki geçişlerde çoğunlukla basit kesme kullanarak anlatının zamansal akışını muğlâklaştırır. Çok nadir olarak uzun süreli eksiltileri vurgulamak için birkaç açılma, kararma ve geçiş planına başvurur. Erksan'ın daha 1960'ta zincirlemeden tümüyle vazgeçmesi modern dekupajın evrimi bağlamında oldukça yenilikçidir. Mesela aynı dönemde Yeni Dalga akımıyla altüst olan ve kabuk değiştiren Fransız sineması bile bunu ancak 1962'de Louis Malle'nin Vie Privée filmiyle yapabilmiştir. ${ }^{25}$ Onun bilinçli biçimsel tercihleri; halkın belirli bir kesiminin durumunu, tarihsel hakikate bağlı kalarak, toplumsal bir içerik ve gerçekçi bir yaklaşım içinde işleyen Gecelerin Ötesi'ne modern sinema estetiğinin özelliklerini kazandırmaktadır.

\section{Sonuç}

1960 senesi biterken gösterime çıkan Gecelerin Ötesi filmi polisiye türünün başat anlambilimsel bileşenlerini ve suç temsilini merkeze alan sözdizimsel anlatı yapısını kullanırken tamamen toplumsal gerçekçi bir öze dayanır. Çeteleşen bir grup delikanlı tarafından işlenen kolektif suçun toplumsal, iktisadi, ruhbilimsel kökenlerine inerken polisiye ile toplumsal gerçekçiliği bağdaştırır, iç içe geçirir ve harmanlar. 
1950’li yıllarda yani Yeşilçam sinemasının oluşum aşamasında standartlaşan bu popüler türün tematik konvansiyonlarını, melodramatik kalıplarını kıran Gecelerin Ötesi'nin sahip olduğu trajik tema ve modern üslup özellikleri bu türle birlikte Türk sinemasına da hem biçimde hem içerikte yenilik getirmeyi başarır. Suç temasını neden, niçin ve nasıl sorularına cevap arayarak işleyen Gecelerin Ötesi'nde yakın geçmişi (yani 1950’lerin Türkiye’sini) betimleyen kimi suçlar değil, aksine 1960’ların başındaki güncel hayatın sıradan bir parçasına dönüşmüş tanıdık bir suçun temsilleri yansitılır.

Erksan'ın eleştirel polisiyesinde gençleri suça iten toplumsal sebepler, suçun temsili; suç soruşturmasının düzenin koruyucusu kolluk kuvveti temsilcisi polisler tarafından başlatılması; ana suçların (çeteleşme, soygun, cinayet, hırsızlık) devam etmesi, polis tahkikatının ipucu, varsayım, tanıkları dinleme, doğrulama şemasına uygun şekilde hızla ilerlemesi; suçluların tespiti ve adaletin tecellisi (cezalandırma, ölüm, hapis) sırayla yer alır. Doğrudan yaşamdan alınan konunun, bağlı bulundukları ekonomik sistemin kurbanları oldukları anlaşılacak aynı alt sosyal çevreden bir grup gencin öyküsüne kaynaklık etmesi senaryocu-yönetmeni o güne kadar Türk sinemasının gördüğü en gerçekçi anlatı kişilerini sergilemeye yöneltir. Kolektif suçu ortak anlatı kişileri etrafında çözümleyen Erksan bu radikal ve eleştirel tavrı sayesinde melodram türüyle sembiyotik ilişkiye giren dönemin polisiyelerinin uzlaşımlarını kırar ve bu türü yenileştirir. Onun biricik imzasını taşıyan Gecelerin Ötesi sanatı yansıtıcı estetik karakteriyle gerçek bir modern sinema eseridir çünkü resimden, müzikten bilhassa yüksek edebiyatın roman türünden ve tabii ki tiyatrodan bahsetmektedir.

$\mathrm{Bu}$ çalışmada türsel kimliği Türk sinema tarihyazımında neredeyse görmezden gelinen ve sadece istisnai bir yaratıcı yönetmenin toplumsal gerçekçi sinema hareketini başlatan öncü bir eseri olarak çözümlenen Gecelerin Ötesi'ni tarihsel açıdan açıklamak ve gelenek içine yerleştirebilmek için çoklu (yazılı, grafik, sözlü, filmsel, filmsel olmayan) kaynakların kullanımına, kesiștirilmesine, karşılaștırılmasına önem verildi. Gecelerin Ötesi'ni ilgilendiren yan metinlerin ve üst metinlerin karşılaştırmalı çözümlemesi bu filmin herhangi bir türle ilişkilendirilmediğini, türsel bilinçle kavranmadığını, türsel etiketlemeye maruz kalmadığını ve tabii ki sosyal içeriği üzerinde özenle durulsa da Türk sinema tarihinde toplumsal gerçekçi hareketi başlatan bir film olarak görülmediğini ispatladı. Birinci el belgelerin kullanımına ve bağlamlaştırmaya dayalı yeni sinema tarihi çerçevesinde hareket eden bu yöntembilimsel tavır, sinema türünü basit bir tipoloji etkinliği ya da sınıflandırma çalışması olarak değil de, meşakkatli bir yorumlama işlemi hatta kategorisi olarak kabul ederek onu a posteriori tanımlamak isteyen Raphaëlle Moine'ye ait kuramsal çerçeve ile desteklendi.

Böylece sinematografik eser incelemesi yapılırken, Yeşilçam denen ticari film yapım sisteminin zoraki koşulları içinde kendisini ispat etmek zorunda kalan auteur yaratıcılığı ile türselliğin yani eserin türsel kimliğinin nasıl bir estetik etkileşime girdiği çözümlendi. Gecelerin Ötesi'nin polisiye türünü, toplumsal bağlam tarafından belirlenen dramatik yönünü ve toplumsal olarak tanımlanan gerçekçi estetiğini birlikte çözümleyen bu örnek olay çalışması aslında Türk sinema tarihinde bir dönüm noktası olan toplumsal gerçekçi sinema hareketini meydana getiren diğer filmlerin de hangi türlerle nasıl ve neden etkileşime girdiğini çözümlemek için bir örnek oluşturabilir. 
Erksan'ın öncüsü olduğu bu sinema hareketine dâhil iki köy filminden Yılanların Öcü ve Susuz Yaz, Yeşilçam sinemasının olmazsa olmaz köy filmi kategorisini kalıplaşmış melodramatik temsillerin dişına çıkararak trajik, gerçekçi ve toplumsal (mülkiyet sorunu) bir temele yerleştirmektedir. Benzer şekilde sınıf atlama temasına odaklanan Acı Hayat sosyal bir melodram olarak, suç meselesini tamamen sınıfsal bir bakıştan inceleyen burjuvazi karşıtı Suçlular Aramızda ise sosyal bir polisiye şeklinde çözümlenmeyi beklemektedir. Son tahlilde, Türk sinema tarihyazımında artık yapılması gereken toplumsal gerçekçi sinema hareketine giren bütün filmlerin türsel kimliklerini ayrıntılarıyla keşfetmektir.

\section{Notlar}

${ }^{1}$ Oysa auteur eleştirisinin ortaya çıktığı Fransa'daki sinema araştırmaları, auteur ile tür arasındaki zıtlığı pekiştiren dikotomik tavrı çoktan aşmıştır. Auteurler içinde en ayrıcalıkı yere sahip Jean-Luc Godard'ın filmleri bile artık tür sineması ile olan estetik bağları etrafında çözümlenmektedir. Mesela Yeni Dalga ve Godard uzmanı Marie (2005, 8183), modern sinemanın dönüm noktası Serseri Âşıklar filmini polisiye tür kapsamında tahlil etmektedir. Marie, Yeni Dalga'nın bu kült filmi ve diğerleri hakkında çözümleme yaparken on beş Godard filminin gösterime çıktıkları ilk anda bizzat eleştiri kurumunun tasdiklediği türsel etiketleri kullanmaktadır.

${ }^{2}$ Yönetmen Erksan, Susuz Yaz'da başrolde oynayan Ulvi Doğan'la birlikte bu filmin ortak yapımcısıdı. Sadece yönetmene ait Troya Film şirketi tarafından çevrilen Sevmek Zamanı ise Erksan'ın hem yazıp hem yönetip hem de bizzat yapımcıı̆ı̆ını üstlendiği ilk filmidir. Türk sinemasına damga vuran bu iki filmin üretim tarzları düşünüldüğünde Erksan'ın bir sinemacı olarak yarı bağımsızlıktan tam bağımsızlığa geçtiği kolayca anlaşlır.

${ }^{3}$ Kelimenin Batıı anlamıyla sanat filmi demek kurumsallaşmış bir film pratiği demektir. Batı Avrupa'da sanat sinemasl; yapım şirketlerini, dağıım ağlarını, devlet desteğini ve tabii ki belirli bir izleyici grubunu (yani entelektüel seçkinleri) kapsayan kurumsal bir bütündür. Bkz. Kovács, 2010, 22 ve 25-26. Sanat filmi/sanat sineması kavramları henüz sinemanın sessiz döneminde yani sinemanın yedinci sanat olarak kabul edildiği 1920 'lerde ortaya çıksa da 1950'ler sanat filminin kurumsallaşmasında çok önemli bir dönemdir. Kovács'ın (27) açıkça belirttiği gibi “1950'lerin ikinci yarısında Avrupa'da sanat-filmi [...] vergi yasalarının, meslek birliklerinin, yapım ve dağııım ağlarının, film festivallerinin ve prestijli dergilerin desteklediği güçlü bir kurum haline gelmişti." Sinemacı Erksan'ın yönetmen olarak en aktif olduğu 1960'lı yıllar düşünüldügünnde Türkiye'de sanat sineması kurumunu oluşturacak ve nitelikli eserleri eğlence yanı ağır basan Yeşilçam ürünlerine karşı destekleyecek bir ulusal kültür/sinema politikasının yürütülmediği hatıllanmalıdır.

${ }^{4}$ Filmde sosyal eşkıyalık meselesinin nasıl, niçin ve ne kadar doğru olarak ele alındığını anlamak için şu çözümlemeye bkz. Yıldırım, 2017, 49-68.

${ }^{5}$ Akad dönemin revaçta olan popüler türü köy filminin melodramatik estetiğini gerçekçi tarafı ağır basan Beyaz Mendil (1955) ile aşmıştır. Kırsal kesimdeki bazı toplumsal sıkıntıları ekrana taşıyan, öyküsünde Yaşar Kemal imzası bulunan filmin ayrıntıı çözümlemesi için bkz. Yıldıım, 2014, 183-188.

${ }^{6}$ Akla ilk gelen Dogma 95 hareketine mensup kolektif yönetmenler bildirisinin mesajı doğrudan veren sekizinci ilkesidir: "Tür filmleri kabul edilemez." Bkz. Delaporte, 2015, 32.

${ }^{7}$ Fransa'da Gaumont şirketi için çok sayıda yeraltı cinayet dizisi (Fantômas, Les Vampires, Judex vs.) yöneten Fransız yönetmen. Bkz. Singer, 2003, 138.

${ }^{8}$ Eleştirel söylem analizi üzerinden hâkim türleri tanımlayarak yönetmen merkezli Türk sinema tarihi yazımını aşan ve standart tür sinemasının belli başlı örneklerini tetkik eden örnek bir çalışma için bkz. Yıldııı, 2016b, 57-215.

${ }^{9}$ Bu polisiye Arpad'ın başkanı olduğu TFDD'nin düzenlediği Birinci Türk Film Festivali'nde en iyi film, en iyi yönetmen, en iyi senarist ve en iyi görüntü yönetmeni ödüllerini alır. Bkz. Vatan, 1953, 1 ve 7. Dönemin popüler sinema mecmuası Yıldız okuyucuları yani sinema seyircileri de Kanun Namına'yı yılın en iyi filmi seçmiştir. Bkz. Yıldız, 1953, 15. Ortada hem eleştirmen grubu hem de seyirci kesimi tarafından tanınan ve sevilen bir tür filmi vardır.

${ }^{10}$ Fransız yönetmen Jules Dassin'in 1948'de ABD'de çevirdiği bu polisiye, New York sokaklarını Italyan Yeni Gerçekçi sinema estetiğini anımsatan belirgin bir üslupta filme alır.

${ }^{11}$ TFDD'nin düzenlediği İinci Türk Film Festivali'nde Akad, Öldüren Şehir'le bir kez daha "başarııı rejisör mükâfatını" almayı başarır. Bkz. Arpad, 1954b, 4. 
${ }^{12}$ Yıldııım'ın detaylı analizine göre (2016b, 127), “Kanun Namına biçimde film noir’a içerikte ise suç melodramına yakın melez bir polisiyedir." Polis aksiyonu ile başlayan filmin olay örgüsü suç teması etrafında döner (128). Çizgisel anlatımı bozan öznel bir geri dönüş kullanımı (129), suçun olası toplumsal ve iktisadi sebeplerini değil de, seri cinayetlere sebep olan ailevi facianın ortaya çıkışını izah eder. Böylece suçun kişisel nedenlerini (intikam, kıskançık) açıklar. Suçun, cinayetin ve yozlaşmanın mahvettiği geleneksel alt-orta sınıf şehirli bir ailenin merkezde olduğu anlatı, soruşturmanın temsiline değil de katil ile polis arasındaki uzun süren takip-kovalamacaya dayanır (127).

${ }^{13}$ Tuğrul (1954) ve bilhassa Solelli'nin (1954) eleştiri metinleri filmin patetik konusunu -örtük bir tarzda da olsamelodramatik öğelerine değinerek uzunca özetlemeyi inmal etmez.

${ }^{14}$ Türkiye'de sinema arşivi denince ilk akla gelen kurum olan Mimar Sinan Üniversitesi Güzel Sanatlar Fakültesi Sinema-TV Merkezi'nin Ocak 2006'da düzenlediği Lütfi Akad 90 Yaşında isimli toplu gösteride bu filme yer verilmemiştir.

${ }^{15}$ Yıldırım melodramın ihanet entrikası üzerine kurulu bu filmin senaryosunun Kanun Namına'nınkinin bir çeşitlemesi olduğunu iddia eder (bkz. 167-168). Suç olarak işlenen namus cinayeti, katil ile polis arasında takip-kovalamaca sahnelerine yol açsa da ortaya basit bir macera havası çıkarır (bkz. 170-171). Öznel geçmişe dönüşlerle karmaşık şekilde yapılandırımış anlatının merkezinde anti-kahraman olarak erkek egemenliğini değil de, kutsal aile düzenini tehdit eden ve dişil bir düşman olarak şeytanlaştıılan düşmüş ve kötü kadın karakter vardır (bkz. 168-169).

${ }^{16}$ Yıldırım'a göre, olay örgüsü cinayet suçu üzerine kurulu olup, anlatım yine doğrusal işlemez yani geri dönüşlere başvurarak suçun ortaya çıkma sebeplerini ifşa eder. Yine başrolü Işık'a veren Intikam Alevi uzaktan Kanun Namına'dan, yakından ise Kati' den etkilenmiştir (bkz. 132). Yalnız, suç soruşturmasını ve suçlunun takibini dikkatle yürüten hatta yöneten külyutmaz polis komiseri bir anlatı kişisi olarak bu filmde daha belirgindir (bkz. 135).

${ }^{17}$ Yıldııım $(2017,46)$, filmi net biçimde polisiye olarak yorumlar. "Cingöz Recai ise polis ile eroin çeteleri arasındaki takip-kovalamaca öğesini öne çıkaran, buna komiser ile Cingöz Recai arasındaki ezeli rekabeti rahatça eklemleyen, esrarengiz cinayetlerle örülü suç öyküsünü akıcı kamera hareketleri, kısa kurgu, açıklayıcı uzun diyaloglarla işleyen, İstanbul gecelerinin karanlık atmosferini türün Amerikan filmlerindeki örneklerine öykünen bir mizansende yeniden yaratmaya çabalayan ve tüm kötüleri (suçluları) cezalandırmayı unutmayan hızı bir polisiyedir. Biçimsel ve biçemsel yönden Kanun Namına'nın açtığı yoldan ilerlemektedir."

${ }^{18}$ Altıner (26) makul bir sebep göstermeden Yolpalas Cinayet’’ni “durgun bir melodram" şeklinde etiketler. Erksan'ın sınıf atlama sorununa eleştirel yaklaş̧ığı 1962 tarihli sosyal melodram Acı Hayat düşünüldüğünde belki hakıı olabilir. Kim bilir aynı yönetmen aynı temayı belki de aynı film türüne başvurarak işlemiş̧tir.

19 Özön $(2000,714)$ sinemadaki toplumsal gerçekçiliği bir akım olarak şöyle tanımlar: "Önemli toplumsal sorunları gerçekçi bir tutumla ele alıp işleyen, bu sorunları gün ışığına çıkarmaya, çözüm yolları aramaya yönelen sinema akımı." Türk toplumsal gerçekçi sinemasına üç eserle (Şehirdeki Yabancı, Gurbet Kuşları, Haremde Dört Kadın) doğrudan katkı sunan Refiğ $(1967,14)$, oluşumunu 27 Mayıs sonrası yaşanan gelişmelere bağladığı bu akımın tarifini yapan tek sinemacıdır. "14'lerin tasfiyesi, 1961 anayasası, yeni kurulan siyasi partiler ve seçimler toplumumuzun çeşitli meselelerine değişik görüş açılarından bakmaya uygun bir ortam yarattı. 27 Mayıs ertesinin meydana getirdiği bu siyasi canlılık sinemada da etkisini göstermekte gecikmedi. Zaman zaman 'toplumsal gerçekçilik' diye tanımlanan, toplumumuzun yapısını, bu yapı içinde çeşitli katlardan insanların birbirleriyle münasebetlerini anlatmaya çalışan, bir akımın doğmasını sağladı." Türkiye'de toplumsal gerçekçilik, sanatsal bir kavram olarak sadece sinemayı ilgilendirmez. Mesela Berksoy'a göre $(1998,112)$ resim alanında “toplumsal gerçekçi sanat, Türkiye'de ilk örneklerini, Yeniler Grubu'nun çalışmalarıyla 1940'I yıllarda vermiştir." Onun için (111) toplumsal gerçekçilikte amaç "toplum yapısındaki sorunların göz önüne serilmesidir." Oktay (bkz. 2008, 480), toplumsal sorunlarla yakından ilgili Yeniler Grubu'nun 1941'de "Liman" konulu bir sergide "deniz emekçilerinin gündelik yaşam sahnelerini" betimleyen eserleri sergilediklerini yazar. Özel olarak edebiyat, genel olarak da sanat alanında 1950'ler Türkiye'sinde "sosyal realizmin" (yani toplumsal gerçekçiliğin) savunusunu Attila Illhan (1954b, 3) yapar: "Sosyal realizm memleketimizin ve milletimizin meselelerini sosyal ve tarihi bir metodla ele alıp en yeni ve en uygun estetik şekiller içerisinde işleyerek yansıtmaya çalışan bir sanat yoludur." 1960'ların toplumsal gerçekçi sinemacıları İlhan'ın tanımlamasına doğrudan referans vermese de sinemada Türk toplumunun sorunlarını gerçekçi bağlamda yansıtmaya çalıştıları düşünüldüğünde onun sosyal realizm konseptiyle ayrışmadıkları hatta yakınlaşıkları anlaşılabilir.

${ }^{20}$ Türk Toplumsal Gerçekçiliğgi'nin "modernlik-geleneksellik" çizgisi üzerinde ulusal bir kimlik arayışını yansıttığını düşünen Daldal $(2003,108)$ hareketi şöyle kavramsallaştırı: "Türk Toplumsal Gerçekçiliği [...] 27 Mayıs sonrasında genç bir yönetmen kuşağının [... . yeni filizlenen sinema ortamı içerisinde hem ulusal bir sinema dili yaratmak hem de Batının estetik normlarını yakalayabilmek adına verdiği cesur ve candan uğraşı yansıtır." Yalnız, bu bölümdeki Gecelerin Ötesi incelemesinde görülebileceği gibi Erksan'ın gerçekçi estetik tercihlerinin modern sinemanın (Jean 
Renoir, Orson Welles, İtalyan Yeni Gerçekçiliği vs.) başat biçim ve üslup özelliklerini başarılya kullanmakla yetinmediği hatta dekupaj konusunda aşarak yenilik getirdiği dikkatlice tespit edilebilir. Daldal (110-111) tanımladığı Türk toplumsal gerçekçi hareketinin temel özelliklerini beşe ayııı: "1-Akımın merkezinde yer alan yönetmenlerin hepsi siyasal anlamda 'angaje' yönetmenlerdir. 2-Toplumsal gerçekçi akım içerisinde bulunan bütün filmler [...] sıradan insanın sorunlarına eğilir. 3-Yönetmenlerin hepsinde açık bir burjuvazi ve kapitalizm karşıtığı vardır. 4-Filmlerde, sinema dilini zenginleştirebilecek, 0 güne dek yeterince üzerinde durulmamış estetik ve biçimsel yeniliklere girişilir. 5-Tüm filmlerin arkaplanını toplumsal bir olay oluşturur." Daldal'ın sıraladığı bu ana özellikler düşünüldüğünde, beş ilkenin hepsini kapsayan Gecelerin Ötesi tam bir toplumsal gerçekçi filmdir. Ancak, Daldal özelinde Erksan'ın filmlerini (Gecelerin Ötesi, Yılanların Öcü, Susuz Yaz, Suçlular Aramızda ve nedense hareket içine dâhil etmediği Acı Hayat), genelinde ise toplumsal gerçekçi hareketin merkezine koyduğu diğer filmleri, bu eserlerin olası türsel estetik kimliklerini görmezden gelerek tek yönden (yani toplumsal gerçekçi eksenden) çözümlemeyi ve yorumlamayı seçmektedir (Bkz. 2005, 93-116). Bir çeşit örnek olay çalışması olan bu makale ise toplumsal gerçekçi kimliğini kabul ettiği Gecelerin Ötesi filminin aynı zamanda polisiye türü tanımlayan anlambilimsel ve sözdizimsel hangi bileşenleri içerdiğini çözümler.

${ }^{21} 0$ yıllarda film tenkitleri kaleme alan sol görüşlü eleştirmenlerin genel tavrı böyledir. Ekranlarda çok ender rastlanan gerçekçi bir Türk filmi tespit ettiklerinde, eserin türsel kimliğini mutlaka ipham eder ve değerlendirmelerini tür sineması dışında yaparlar. Bkz. Yıldııı, 2016a, 3187-3195.

${ }^{22}$ Filmin biricik yaratıııı Erksan da, eleştirmenlerin ve sinema tarihçilerinin yetersiz yorumlarla değerlendirdiğini düşündüğü Gecelerin Ötesinnin sadece içinde üretildiği toplumla ilişkisine bakan tek yanlı bir yorum yaparken, eserinin türünü ya da türselliğini yeniden tanımlama yoluna gitmemektedir. Bkz. Sönmez ve Öztürk, 1985, 25-26.

${ }^{23}$ Gecelerin Ötesi’nin son planında doğru yoldan sapmayan sıradan iki insanın (şoför Tahsin ile eşi Sema'nın) uzaktan, genel plandan ve üst açı ile alınmış bir görüntüde kendilerini bekleyen müphem geleceğe yürümesi, Akad'ın Yalnızlar Rıhtımı'nın son çekiminde bilinemez bir geleceğe doğru birlikte yürüyen kaptan ile kontesin durumlarını anımsatır. Anlaşlacağı gibi uzak bir çekimden küçücük gösterilen Tahsin ile Sema'yı gelecekte ne beklediği belirsizdir. Gecelerin Ötesinndeki açık uçlu son kullanımı da, anlatının belirsizliğini kendi estetik karakteristiğine dönüştüren İtalyan Yeni Gerçekçiliğine özgü açık uçlu son niteliği ile uyuşmaktadır. Bkz. Bordwell ve Thompson, 2011, 453.

${ }^{24}$ Sinema dilinin evrimini özenle çözümleyen gerçekçi sinema taraftarı André Bazin, çağdaş sinemanın alametifarikası olan alan derinliği ve plan sekans tekniklerini gerçekçi sinema estetiğinin vazgeçilmezleri olarak kabul eder. Ona göre "kamera fiziksel gerçekliği kaydederek" ortaya çıkarırken bu yeni teknikler sayesinde "zamansal devamlıık ve mekansal birlik" korunur. Sonuç olarak ortaya "zamanın ve mekânın ayrılmaz gerçekçiliği" çıkar. Bazin'in bu görüşlerini akt. Bordwell, 1999, 61-62 ve 89.

${ }^{25}$ Hatta eleştirmen Roger Boussinot, ünlü Cahiers du Cinéma dergisinin haftalık kürsüsü olarak görülen Arts dergisinde yayınladığı bir makalesini Türkiye'de Gizli Hayat ismiyle oynayan bu filmdeki zincirleme yokluğundan esinlenerek şu şekilde adlandırmışıı: "Sinemanın Büyük Yeniliği: Zincirlemenin Ölümü". Bkz. Chion, 2002, 198.

\section{Kaynakça}

Algan, N. (2017). Metin Erksan. F. M. Kara (Ed.). Sansür ve Mülkiyetin Karşısında Metin Erksan (s. 25-49). İstanbul: Yitik Ülke Yayınları.

Altıner, B. (2005). Metin Erksan Sineması. İstanbul: Pan.

Altman, R. (2003). Sinema ve Tür. G. Nowell-Smith (Ed.). Dünya Sinema Tarihi (A. Fethi Çev.) (s. 322-333). İstanbul: Kabalcı.

Arpad, B. (5 Aralık 1952). Kanun Namına. Vatan, 4.

.. (23 Ekim 1953a). İstanbul Canavarı. Vatan, 4.

_. (5 Aralık 1953b). 6 Ölü Var. Vatan, 4.

_. (13 Aralık 1953). Katil. Vatan, 5.

_. (17 Şubat 1954a). Öldüren Şehir. Vatan, 4.

_. (3 Ekim 1954b). Üçüncü Kat Cinayeti. Vatan, 4.

_. (30 Ekim 1954c). Cingöz Recai. Vatan, 4.

.. (2 Ocak 1955). Kaçak. Vatan, 5. 
Benzin İstasyonlarını Soyan Bir Hırsız Şebekesi Yakalandı. (8 Nisan 1960). Vatan, 2.

Berksoy, F. (1998). 20. Yüzyıl Batı ve Türk Resminde Toplumsal Gerçekçilik. İstanbul: Kendi Yayını.

Berthé-Gaffiero, C. (2005). Le cinéma policier français de 1930 à 1950 : L'âge d'or du film à l'énigme, le whodunit. R. Moine (Ed.). Le Cinéma français face aux genres (s. 203-212). Paris: AFRHC.

Bordwell, D. (1999). On The History of Film Style. Cambridge, Londra: Harvard University Press.

Bordwell, D. ve Thompson, K. (2011). Film Sanatı: Bir Giriş (E. Yılmaz, E. S. Onat Çev.). Ankara: De Ki.

Butler, A. M. (2011). Film Çalışmaları (A. Toprak, Çev.). İstanbul: Kalkedon.

Chion, M. (2002). Technique et création au cinéma. Le livre des images et des sons. Paris: ESEC.

Cingöz Recai Fotoğrafı. (24 Ekim 1954). Vatan İlave, 4.

Daldal, A. (Ağustos 2003). Türk sinemasında toplumsal gerçekçilik: Bir tanım denemesi. Birikim, 172, 104-112.

_. (2005). 1960 Darbesi ve Türk Sinemasında Toplumsal Gerçekçilik. İstanbul: Homer.

Delaporte, C. (2015). Le genre filmique. Cinéma, télévision, internet. Paris: Presses Sorbonne Nouvelle.

Duru, N. (Yapımcı), Erksan, M. (Senarist), Erksan, M. (Yönetmen). (1960). Gecelerin Ötesi [Film]. Türkiye: Ergenekon Film.

Elsaesser, T. ve Hagener, M. (2011). Film Kuramı. Duyular Yoluyla Bir Giriş (B. Soner, B. Yıldırım, Çev.) Ankara: Dipnot.

Erksan, M. [Kamera]. (28 Ekim 1953a). İstanbul Canavarı. Dünya, 4, 6.

_. (29 Ekim 1953b). Tenkidin Tenkidi. Dünya, 4, 6.

Esin, M. A. (6 Ocak 1957). İntikam Alevi. Pazar Postası, 9.

Film Festivalinin Neticesi Alındı. (30 Nisan 1953). Vatan, 1, 7.

Gecelerin Ötesi Afişi. (1960). Beyazıt Devlet Kütüphanesi Arşivleri.

Gecelerin Ötesi Fotoğrafı. (19 Kasım 1960). Vatan, 4.

Gecelerin Ötesi Film Hikâyesi. (Kasım 1960). Sinema, 3, 6-7, 34.

Gecelerin Ötesi İlanı. (20 Aralık 1960). Yeni Sabah, 5.

Gecelerin Ötesi Reklamı. (Aralık 1960). Yeni Sinema, 3, 18.

Gevgilili, A. (16 Mayıs 1959). Festivallere Giden Yol. Vatan, 2.

İlhan, A. (Şubat 1954a). Türk Sinemasının Estetik Seviyesi. Yeditepe, 55, 3.

_. (Aralık 1954b). Sosyal Realizm Ne Olmak İstiyor. Yeditepe, 74, 3.

İstanbul Kan Ağlarken. (Eylül 1951). Yıldız, 37, 12-13, 24.

İstanbul Rehberi: Sinemalar. (20 Aralık 1960-5 Ocak 1961). Yeni Sabah, 5.

Journot, M-T. (2004). Le vocabulaire du cinéma. Paris: Nathan. 
Jullier, L. ve Marie, M. (2007). Lire les images de cinéma. Paris: Larousse.

Kakınç, T, D. (5 Şubat 1956). Kanlar ile Ödediler. Pazar Postası, 8.

_. (14 Mayıs 1961). Gecelerin Ötesi. Vatan, 4

Kanlarıyla Ödediler. (Aralık 1955). Yeni Yıldız, 30, 23.

Karamahmut, T. (Nisan 1953). Gene Değișmez. Yıldız, 18, 19, 23.

Kayalı, K. (2004). Metin Erksan Sinemasını Okumayı Denemek. Ankara: Dost.

_. (2018). Gelenekselliğin ve Farklılaşmanın İç İçe Geçmesiyle Şekillenen Türk Sineması Geçmişten Kopmadan Yenileşiyor. TRTAkademi, 3(5), 436-443.

Kovács, A. B. (2010). Modernizmi Seyretmek Avrupa Sanat Sinemasl, 1950-1980 (E. Yılmaz, Çev.). Ankara: De Ki.

Kracauer, S. (2015). Film Teorisi. Fiziksel Gerçekliğin Kurtuluşu (Ö. Çelik, Çev.). İstanbul: Metis.

Küçük, Y. (2016). Tenkit. Materyalist Gözleriyle Yazarlarımız. Ankara: Tekin.

Okan, T. (8 Ocak 1956). Yolpalas Cinayeti, Milliyet, 7.

Oktay, A. (2008). Toplumcu Gerçekçiliğin Kaynakları. Sosyalist Realizm Üstüne Eleştirel Bir Çalışma. İstanbul: İthaki.

Özdeş, O. (26 Aralık 1955). Kanlarıyla Ödediler. İstanbul Ekspres, 3, 5.

Özgüç, A. (Mayıs 1961). Festival ve Ötesi. Sinema, 29, 11-12.

_. (2005). Türlerle Türk Sineması Dönemler - Modalar - Tiplemeler. İstanbul: Dünya Kitapları.

Özkırım, Ç. A. (18 Kasım 1960). Gecelerin Ötesi. Yeni Sabah, 4.

Özön, N. (1961). Üç Film. Türk Dili, 112, 216-219.

_. (1962). Türk Sinema Tarihi. Dünden Bugüne: 1896-1960. İstanbul: Artist Reklam.

. (1968). Türk Sineması Kronolojisi (1895-1966). Ankara: Bilgi.

_. (2000). Sinema, Televizyon, Video, Bilgisayarlı Sinema Sözlüğü. İstanbul: Kabalcı.

_. (2013). Türk Sineması Tarihi 1896-1960. İstanbul: Doruk.

Marie, M. (2005). Godard et la notion de genre. R. Moine (Ed.). Le Cinéma français face aux genres (s. 79-86). Paris: AFRHC.

Mayk Hammer: Bu Gece Son Gecesi. (19 Kasım 1955). Milliyet, 3.

Mitry, J. (1980). Histoire du cinéma Art et Industrie Vol. 4 - les années 1930. Paris: Editions Universitaires.

Moine, R. (2004). Le genre cinématographique : une catégorie de l'interprétation. Belphégor, 3(1), 1-10.

_. (2008). Les genres du cinéma. Paris: Armand Colin.

_. (2009). Film, genre et interprétation. Le français aujourd'hui, 2(165), 9-16.

Nagip, L. (2017). Realist cinema as world cinema. R. Stone ve P. Cooke (Ed.). The Routledge Companion to World Cinema (s. 310-322). Abingdon-on-Thames: Routledge. 
Panel: Türkiye'de 1960'lar ve Sinema, (23 Ocak 2007). H. B. Kahraman (Düz.). Metin Erksan, Halit Refiğ, Ertem Göreç (Katılımcılar). İstanbul: Akbank Sanat.

Pillard, T. (2012). Une histoire oubliée : la genèse française du terme "film noir" dans les années 1930 et ses implications transnationales. Transatlantica, (1), 2-18.

Pinel, V. (2009). Genres et mouvements au cinéma. Paris: Larousse.

Refiğ, H. (Mart 1956a). Ebediyete Kadar. Akis, 96, 27.

_. (Eylül 1956b). Festivaller. Akis, 121, 26.

.. (Kasım 1956c). İntikam Alevi. Akis, 133, 24.

_. (Aralık 1960). Bir İyi Niyet Gösterisi. Akis, 337, 34.

_. (Haziran 1967). Bende de Kara Sevda Var-II. Yön, 219, 14-15.

Rejisör Metin Erksan Sinemadan Ne Anlıyor? (15 Mayıs 1962). Ataç, 1, 31.

Scognamillo, G. (2003). Türk Sinema Tarihi. İstanbul: Kabalcı.

Singer, B. (2003). Diziler. G. Nowell-Smith (Ed.). Dünya Sinema Tarihi (A. Fethi Çev.) (s. 134-148). İstanbul: Kabalcı.

Solelli, S. [Lüks Koltuktaki Adam]. (Aralık 1952). Kanun Namına. Yıldız, 102, 7, 21.

_. (Mart 1953a). Kanlı Para. Yıldız, 13, 21.

.. (Mayıs 1953b). Affet Beni Allah'ım. Yıldız, 19, 15.

_. (Şubat 1954). Öldüren Şehir. Yıldız, 61, 3.

Sönmez, H. ve Öztürk, S. (1985). Metin Erksan: Türkiye'de Entelijansiya Yok. Ve Sinema, 1, 24-38.

Stam, R. (2014). Sinema Teorisine Giriş (S. Selman ve Ç. Asatekin, Çev.). İstanbul: Ayrintl.

Teksoy, R. (2007). Rekin Teksoy'un Türk Sineması. İstanbul: Oğlak.

Thompson, K. ve Bordwell, D. (2003). Film History: An Introduction. New York: McGraw Hill.

Thoraval, Y. (1996). Aujourd'hui et hier, le cinéma turc : le point de vue d'un amateur. CEMOTI : Cahiers d'Études sur la Méditerranée Orientale et le Monde TurcoIranien, 22, 357-366.

Tuğrul, S. [Sinopsis]. (7 Kasım 1953). Altı Ölü Var. Dünya, 4.

_. (14 Şubat 1954). Öldüren Şehir. Dünya, 4.

Türk Sineması İçin Hürriyet Beyannamesi. (13 Haziran 1960). Vatan, 5.

Türkiye 1960: Gecelerin Ötesi. (Nisan 1960). Akis, 299, 32-33.

Üyepazarcı, E. (Aralık 2015-Ocak 2016). Dudaklarıyla Dövüşür, Yumruklarıyla Sevişir!. Atlas Tarih, 37, 100-107.

Vanoye, F. ve diğerleri. (2000). Le Cinéma. Paris: Nathan.

Ylldırım, T. (2014). Une période emblématique du cinéma turc: Le cinéma de Yeşilçam (1948-1971). İstanbul: Isis Press \& IFEA. 
_. (2016a). 1950’ler Sonu Türk Sinema Eleştirisinin “Türsüzleștirme” Uygulaması: Üç Arkadaş (1958) ve Yalnızlar Rıhtımı (1959) Melodramlarının Eleştirel Alımlamaları ve Estetik Çözümlemeleri. International Journal of Human Sciences, 13 (2), 3181-3203.

- (2016b). Türk Sinemasının Estetik Tarihi. Standart Türlere Giriş: 1948-1959, İstanbul: ES.

•. (2017). Sinemacı ve Tarihçi Metin Erksan. Dokuz Dağın Efesi'nde Sosyal Eşklyalık Meselesi. İstanbul: ES.

•. (2018). İntikam Alevi'nde Sovyet Montaj Üslubu Örneği. TRTAkademi, 3(5), 112137.

Yildız Mükâfatı. (Ağustos 1953). Yıldız, 36, 14-17.

Yolpalas Cinayeti. (12 Ağustos 1955). Yeni Yıldız, 11, 28.

Yolpalas Cinayeti. (12 Ocak 1956). Yeni Ylldız, 33, 25.

\section{Ekler}

\section{Gecelerin Ötesi Basın Özel Gösterimi:}

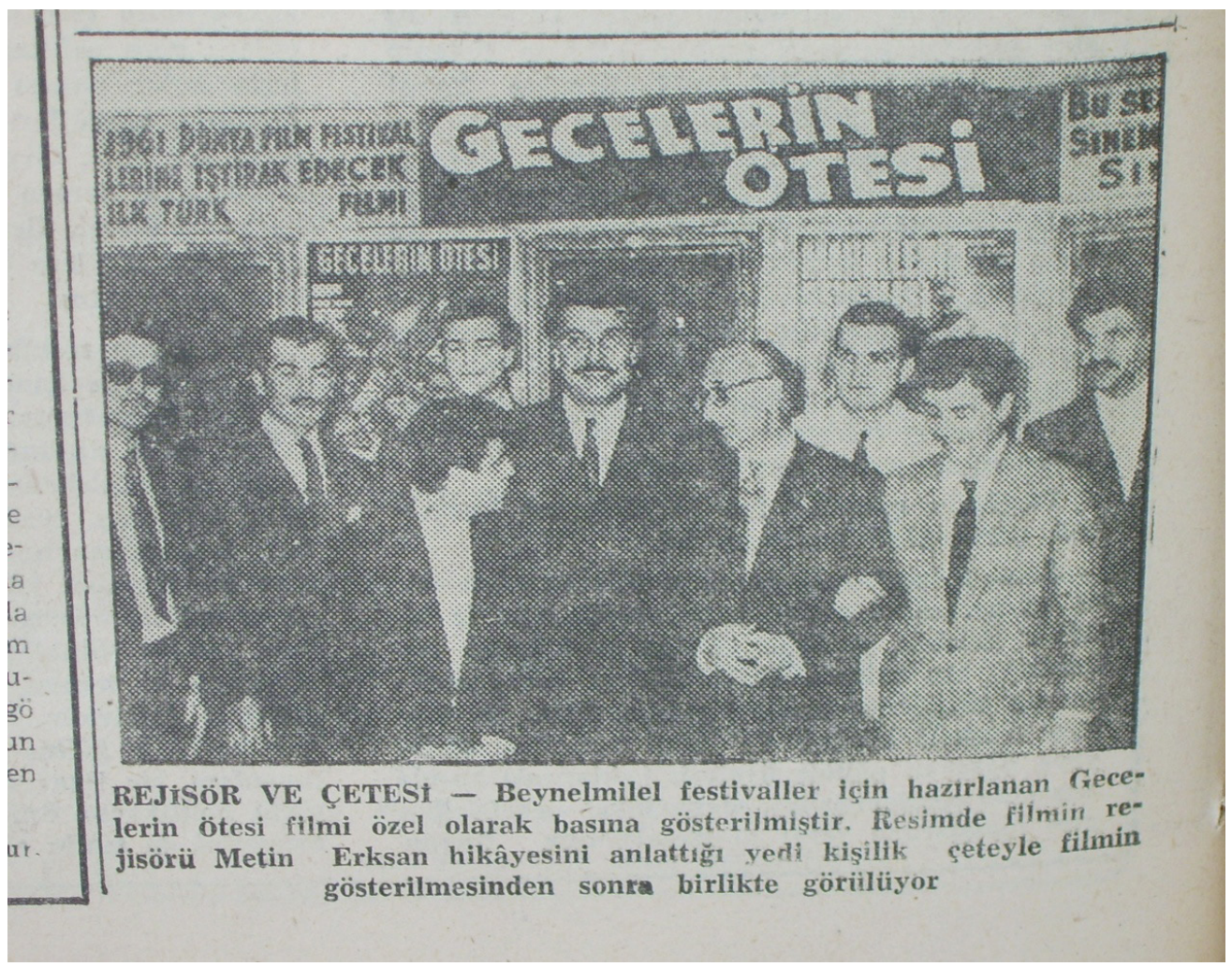

Kaynak: Vatan, 19 Kasim 1960, s. 4.

Metin Erksan (ön sırada en sağdaki siyah kravatlı olan), TSSD (Türk Sinema Sanatçıları Derneği) Başkanı Baha Gelenbevi (gözlüklü olan) ile kol kola girmiş. Filmde yar alan bazı oyunculardan (sağdan sola) Erol Taş, Oktar Durukan, Kadir Savun, Metin Ersoy, Hayati Hamzaoğlu arkada ve Suphi Kaner (yüzü sağa dönük) en önde kalmış. En solda gözlüklü olan kişinin kim olduğunu (yapımcı, Nejat Duru?) kesin olarak söylemek zor. Fotoğrafın altında verilen açıklayıcı yazıda ise önemli bir hata yapılıyor çünkü Gecelerin Ötesi'nde yedi kişilik bir çetenin öyküsü değil de altı kişilik bir çetenin öyküsü anlatılır. 


\section{Gecelerin Ötesi illânı:}

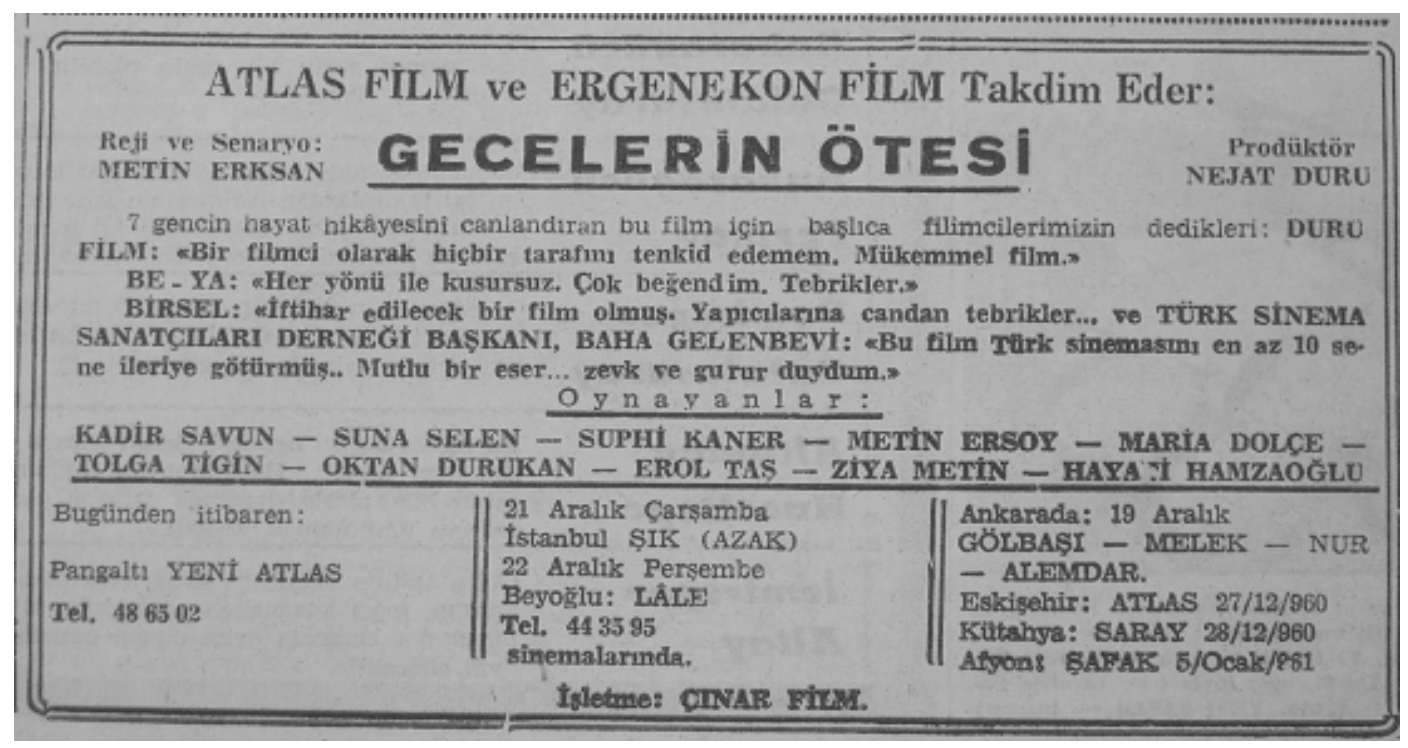

Kaynak: Yeni Sabah, 20 Aralık 1960, s. 5.

Ergenekon Film tarafından yapılan ve Çınar Film tarafından da işletilen Gecelerin Ötesi'nin bu gazete ilânında dönemin bazı yapımcı firmaları (Duru Film, Be-Ya Film ve Birsel Film) ile TSDD Bașkanı Baha Gelenbevi'nin film hakkındaki olumlu görüșlerine de yer verilmiş. İlân, filmin Pangaltı'daki Yeni Atlas sinemasında gösterime girdiği günde yayınlanmıştır. Filmin Ankara, Eskișehir, Kütahya ve Afyon gibi bazı Anadolu șehirlerinde hangi tarihlerde gösterime gireceği de belirtilmiștir. İlânda filmin yapımcısı Nejat Duru'nun babası Nazif Duru'nun sahibi olduğu Atlas Film'in yer alması, Gecelerin Ötesi'nin ön gösteriminin ve ilk ticari gösterimin Duru ailesinin işlettiği Yeni Atlas sinemasında yapılmasıyla sıkı sıkıya bağlantılıdır. 


\section{Gecelerin Ötesi Reklâmı}

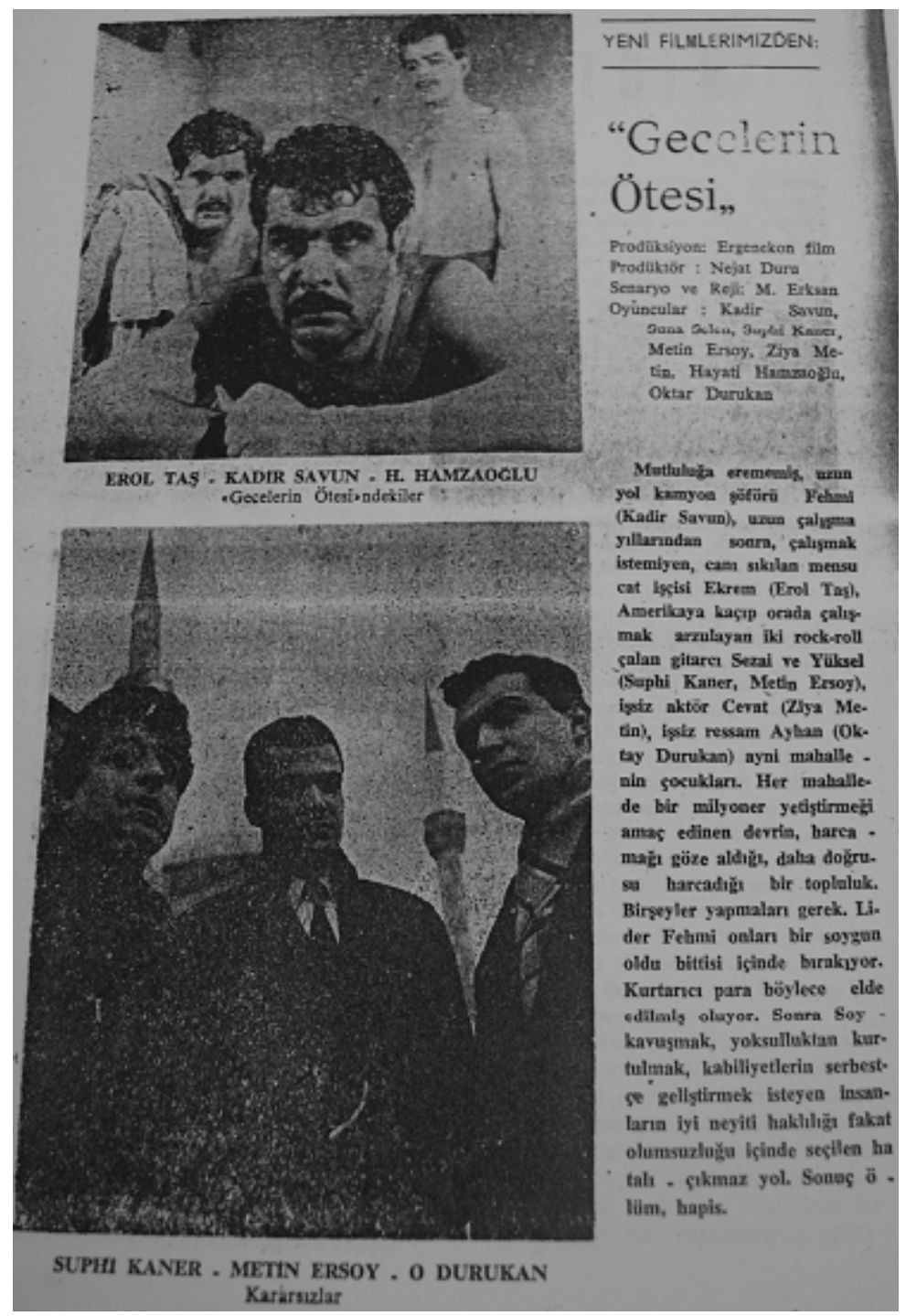

Kaynak: Yeni Sinema, sayı: 3, Aralık 1960, s. 18.

Gecelerin Ötesi'nin tanıtım amacıyla, dönemin sinema dergilerinden (eleştirmenler Ali Gevgilili ve Tarık Kakınç tarafından sinema kültürünü Türkiye'de yaymak amacıyla çıkarılan Yeni Sinema) birinde yayımlanmış reklâmı: Filmin ismi, yapımevi, yapımcl, senaryocu, yönetmen ve filmde yer alan oyuncuların bir kısmından oluşan kısa bir jenerik, filmin konusunu temel hatları ile (siyasi mesajı da ekleyerek) veren kısa bir özet ve iki adet çalışma fotoğrafı kullanılmış. 